\title{
NeUtralization OF THE TAP/Trill Contrast in the Bilingual Creole- Spanish Community of the Archipelago of San Andres, Colombia
}

\author{
NEUTRALIZACIÓN DEL CONTRASTE FONÉMICO EN LA COMUNIDAD BILINGÜE HABLANTE \\ de CREOl y español en el archipiélago de San ANdrés, Colombia
}

NeUtralisation du CONTRASTE PHONÉmiQue PaRmi la COMMUNAUté bilingue CrÉole-eSPagnole de l'archipel de SAN ANdrés, Colombie

NeUTRALIZAÇão do CONTRASTE FONÊMICO NA COMUNIDAdE BILÍNGUE CRIOULAespanhola do Areuipélago de San Andrés, Colômbia

\section{Falcon D. Restrepo-Ramos}

Assistant Professor, Minnesota State

University at Mankato, USA.

falcon.restreporamos@mnsu.edu

https://orcid.

org/0000-0002-0839-7001

\begin{abstract}
This study examines the segmental duration of non-vibrant rhotics in a language contact scenario in the Western Caribbean, where an English-based Creole coexists with Spanish: The Archipelago of San Andres, Colombia. The unexplored phenomenon of the neutralization of the tap/trill contrast merits a thorough analysis to examine the effects of language contact in this Creole-Spanish bilingual population. To do this, the segmental duration of 619 non-vibrant, intervocalic taps and trills were compared in three generations of Raizal Spanish (the bilingual Spanish variety) and contrasted with the duration of Continental Spanish (the monolingual variety spoken by Colombian immigrants from Continental Colombia). While there are language-specific differences in rhotic duration between Creole and Spanish, results show that Raizal Spanish has longer durations that differ from the monolingual Spanish variety. A cross-generational examination revealed that the neutralizations of the tap/trill contrast in older bilinguals, as third-generation speakers, are converging toward the monolingual variety, distancing themselves from the older second and first generations. This phenomenon signals a change in progress resulting from diverging variation patterns of duration in tap/trill segments in generations of bilingual Raizales. These findings suggest a changing sociolinguistic panorama in which stable bilingualism is taking place among younger individuals.
\end{abstract}

Keywords: Archipelago of San Andres; non-vibrant rhotics; Raizal Spanish; Creole; segmental duration; language contact; neutralization; tap/trill contrast.

Received: 2021-02-09 / Accepted: 2021-09-22 / Published: 2022-02-11

https://doi.org/1017533/udea.ikala.v27n1a07

Editor: Doris Correa, Universidad de Antioquia, Medellín, Colombia.

Some rights reserved, Universidad de Antioquia, 2022. This is an open access article distributed under the terms of the under the Creative Commons license BY-NC-SA 4.0 International. 


\section{RESUMEN}

Este estudio examina la duración segmental de las róticas no vibrantes en una situación de contacto originada en el caribe occidental donde un creol de base inglesa coexiste con el español: el Archipiélago de San Andrés, Colombia. Este fenómeno no explorado de la neutralización del contraste de las róticas no vibrantes simples y múltiples amerita un análisis exhaustivo para examinar los efectos del contacto lingüístico en esta población bilingüe creol-español. Se comparó la duración segmental de 691 róticas no vibrantes (simples y múltiples) en posición intervocálica a través de tres generaciones de hablantes del español raizal (la variedad del español bilingüe) y se contrastó con la duración producida por hablantes del español continental (la variedad monolingue hablada por los immigrantes colombianos de la Colombia continental). Aunque existen diferencias específicas entre el creol y el español, los resultados de los datos bilingües muestran que el español raizal tiene duraciones más extensas que difieren de la variedad de español monolingüe. $\mathrm{Al}$ examinar las diferencias intergeneracionales se encontró que los hablantes de primera y segunda generación neutralizan el contraste de las variantes simples y múltiples, mientras que los hablantes más jóvenes convergen hacia la variedad monolingüe, distanciándose, a la vez, de sus contrapartes mayores. Este fenómeno indica un cambio lingüístico resultado de patrones divergentes de variación en la duración segmental entre generaciones de raizales bilingües. Estos resultados sugieren que existe un panorama sociolingüístico cambiante en donde un bilingüismo estable está tomando lugar en la población más joven del archipiélago.

Palabras claves: Archipiélago de San Andrés; róticas no vibrantes; español raizal; creol sanandresano; duración segmental; contacto lingüístico; neutralización; contraste fonémico.

\section{RÉSUMÉ}

Cette étude examine la durée segmentale des rhotiques non vibrants dans une situation de contact dans la Caraïbe occidentale où un créole à base anglaise coexiste avec espagnol: l'Archipel de San Andrés, Colombie. Le phénomène inexploré de la neutralisation du contraste tap/trill mérite une analyse approfondie pour examiner les effets du contact linguistique dans cette population bilingue créole-espagnol. La durée segmentale de 691 rhotiques non vibrants (simples et multiples) en position intervocalique a été comparée sur trois générations de hispanophones Raizales (l'espagnol bilingue parlé par les immigrants colombians de la Colombie continentale) et contrastée avec la durée produite par les hispanophones continentaux. Bien qu'il y ait des différences spécifiques entre le créole et l'espagnol, les résultats des données bilingues montrent que l'espagnol raizal a des durées plus longues qui diffèrent de la variété monolingue de l'espagnol. Un examen intergénérationnel a révélé la neutralisation du contraste de variantes simples et multiples chez les bilingues plus âgés, alors que les jeunes hispanophones convergent vers la variété monolingue, se distanciant de la génération plus âgée. Ce phénomène indique un changement linguistique résultant de modèles divergents de variation de la duration segmentale entre des générations des bilingues raizales. Ces résultats suggèrent un panorama sociolinguistique changeant, dans lequel un bilinguisme stable a lieu parmi les individus plus jeunes.

Mots clés : Archipel de San Andrés; rhotiques non vibrants; espagnol raizal; créole; durée segmentale; contact linguistique; neutralisation ; contraste phonémique. 


\section{RESUMO}

Este estúdio examina a duração segmentar das róticas não vibrantes em uma situação de contato originada no Caribe ocidental onde um crioulo de base inglesa coexiste com o espanhol: el Arquipélago de Santo André, Colômbia. O fenômeno inexplorado da neutralização do contraste de róticos não vibratórios simples e múltiplos merece uma análise minuciosa para examinar os efeitos do contato linguístico nessa população bilíngue crioulo-espanhol. A duração segmentar de 691 ritmos não vibratórios (simples e múltiplos) em posição intervocálica foi comparada ao longo de três geraçôes de falantes de espanhol raizal (a variedade do espanhol bilíngue) e contrastada com a duração produzida por falantes de espanhol continental (a variedade monolíngue falada pelos migrantes colombianos da Colômbia continental). Embora existam diferenças específicas entre o crioulo e o espanhol, os resultados dos dados bilíngues mostram que o espanhol raizal tem durações mais longas que diferem da variedade monolíngue do espanhol. Ao examinar as diferenças intergeracionais, verificou-se que falantes de primeira e segunda geração neutralizam o contraste de variantes simples e múltiplas, enquanto falantes mais jovens convergem para a variedade monolíngue, distanciando-se, ao mesmo tempo, de seus homólogos mais velhos. Este fenômeno indica uma mudança linguística como resultado de padrões divergentes de variação na duração segmentar entre gerações de raizais bilíngues. Esses resultados sugerem que há uma mudança no cenário sociolinguístico onde o bilinguismo estável está ocorrendo na população mais jovem do arquipélago.

Palavras-chave: Arquipélago de Santo André; róticos não vibratórios; espanhol raizal; crioulo de Santo André; duração do segmento; contato linguístico; neutralização; contraste fonêmico. 


\section{Introduction}

This study examines the realization of the tap/ trill contrast in a bilingual variety of Spanish that emerged through contact between a Western Caribbean Creole and the national language of Spanish. The Archipelago of San Andres, Colombia, is home to a language contact situation, where an English-based Creole known as Islander coexists with an immigrant, monolingual, Spanish variety from mainland Colombia (henceforth Continental Spanish). In this territory, a Creole-speaking, AfroCaribbean population self-denominated with the ethnonym of Raizal people (Raizales) coexists with continental Colombian Spanish producing a bilingual Spanish variety referred here, as Raizal Spanish. This term has been coined by the Creole community as a way to be officially recognized by the Colombian government as an ethnic group. The 'Raizal' term is also intended to distinguish themselves from other Afro-descendants of mainland Colombia.

For this work, taps and trills in word-medial, intervocalic position involving an absence of an occlusion phase (i.e., non-vibrant) were examined across generations of Raizal Spanish and compared to non-vibrant monolingual Continental Spanish variants with the aim of investigating the outcomes of language contact at the phonemic level. There are reports that the tap/trill contrast has been neutralized in some bilingual dialects (Balam, 2013) while in others it has been maintained in the form of segmental duration (Henriksen, 2015; Bradley \& Willis, 2012).

Neutralization of the tap/trill contrast in nonvibrant rhotics might be a signal of ongoing linguistic change in progress resulting from diverging variation patterns of segmental duration in different generations of bilingual Raizal individuals. I test this assumption in the rhotics of the archipelago exploring the effect of segmental variation and linguistic variables, such as word stress, across age-stratified samples in the Raizal population.
Documentation of the variable neutralization of the tap/trill contrast in this archipelago sheds light on the effects of contact and the particular social situation of this community, providing an account on how language contact in the Caribbean, and more specifically, the Western Caribbean, is occurring in local Creole communities coexisting with a national non-lexifier language.

\section{Historical and Sociolinguistic Background of the Archipelago of San Andres}

The history of the people of the Archipelago of San Andres has remained under the influence of opposing forces, one representing old and new colonialism and the other representing the diaspora of the Creole people of the Caribbean. The nature of these opposing forces has resulted in the emergence of a series of contrasting social categories that are in common use in the archipelago, such as Hispanophone vs Anglophone/ Creole speaker and Paña ${ }^{1}$ vs Raizal (Ross, 2007).

Islander Creole has a direct kinship with the diaspora of the English-based Creoles of the Caribbean. Its most recent origins can be traced back to the second half of the 1700s, with the arrival of colonists from parts of the British Caribbean, particularly from Jamaica (Bartens, 2013; Ross, 2007). When deconstructing the history of Islander Creole even further, we must go back to the period of the Atlantic slave trade. During the $16^{\text {th }}$ century, European powers were able to expand their empires overseas, thanks to the European "discovery" of the 'New World' in 1492. This led to the inhumane kidnaping and subsequent trafficking of human labor from Africa by the most prolific maritime powers of the time, the Portuguese and the British. For approximately 300 years, slaves were imported to the Americas by a system of human trafficking from the coasts of West Africa. From 1655 to 1725 , a quarter of the slaves brought to Jamaica came from the

1 Paña is a term coined by Raizal natives to refer to Spanish-speaking immigrants from mainland Colombia. 
region of Gambia and Sierra Leone where languages such as Mandinga and Mende or Bende were spoken. According to Holm (1978), they represent the structural base for the Portuguesebased and English-based Creoles in the Caribbean and Krio in Sierra Leone. Similarly, another 25\% of the slaves imported to the Americas came from what was known as the British colony of the Gold Coast, where Akan is the major linguistic group. The same region became a source for a greater percentage of the slave trade to the Americas from 1725 to 1775 .

The phase and location in which the Islander Creole proto-Pidgin turn into a full-fledged nativized Creole language is uncertain and "mostly based on speculations" (Holm, 2000, p. 8). However, it has been revealed that over $17 \%$ of the lexical items in Islander Creole, which also appear in Jamaican Creole, were of African origin (Edwards, 1974). The common ancestry of these lexicons comes from the Twi language, a variety of Akan, spoken in what was known as the African Gold Coast. Another notorious substrate lexifier is Mende from the Southwest coast of Gambia, formerly known as Windward Coast during the time of the slave trade, and Sierra Leone (Dittman, 1992). Commonly, Mende or Bende is sometimes used by Raizal locals to refer to their Creole language, while Islander Creole is a term used to contrast with the language of the mainlanders (i.e., Spanish).

It is important to note that at the onset of the slave trade in 1655, importation of slaves from the feitorias started in the region of current Gambia, Sierra Leone, and the Gold Coast (current Nigeria), reaching its peak in 1775. Precisely, Islander Creole originated from this English-based protoPidgin, which is an offshoot of Jamaican Creole. The archipelago was annexed to the newly formed Republic of Colombia in 1822. By the beginning of the $20^{\text {th }}$ century, most inhabitants of the islands were direct descendants of Creole-speaking AfroCaribbean people (Patiño-Roselli, 1992). From then on, multiple social, economic, and political events produced the current ethnolinguistic situation of the islands.

The ethnolinguistic vitality of the Raizal community and their Creole language has changed dramatically during the last 100 years. At the beginning of the $20^{\text {th }}$ century, it was estimated that a total of 8,000 Raizal people lived in the archipelago (Dittman, 1992). In 2005, the official number reached 23,396 (DANE, 2005) and by 2018, 20,332 self-identified as Raizales, from which only 16,884 speak their native language (DANE, 2018). The commercial expansion of the islands in 1953 resulting from the Freeport declaration brought an ever-increasing influx of business-oriented immigrants until restriction policies were put into place. Consequently, the old sites where Raizal people had traditionally established their communities have now been displaced by hotels, an airport, and an array of multiple businesses.

The conflict over land and means of living have displaced this community to live outside of the commercial spheres of economic and political significance of the islands, and thus Raizal people have settled in neighborhoods where Islander Creole maintains oral transmission and community ascription. In both San Andres and Old Providence, Raizal people have maintained their own close-knit communities, somewhat distant from the fast-paced life of the urban area. In San Andres, Raizal communities tend to settle in neighborhoods, such as The Hill, San Luis, and South End. However, The Hill seems to be the stronghold of the Raizal identity, particularly because this part of the island has little economic interest for commerce and tourism (such as in North End), and it has been historically the location of the First Baptist Church and other English-speaking churches (see Figure 1). As a result, Islander Creole is more preserved in this area of the island.

Old Providence presents a different sociolinguistic landscape, mainly due to its distance from San Andres that has allowed Old Providence to be more 
Figure 1 Island of San Andres with the Location of the Ethnic Neighborhoods and the Downtown Areas Highlighted.

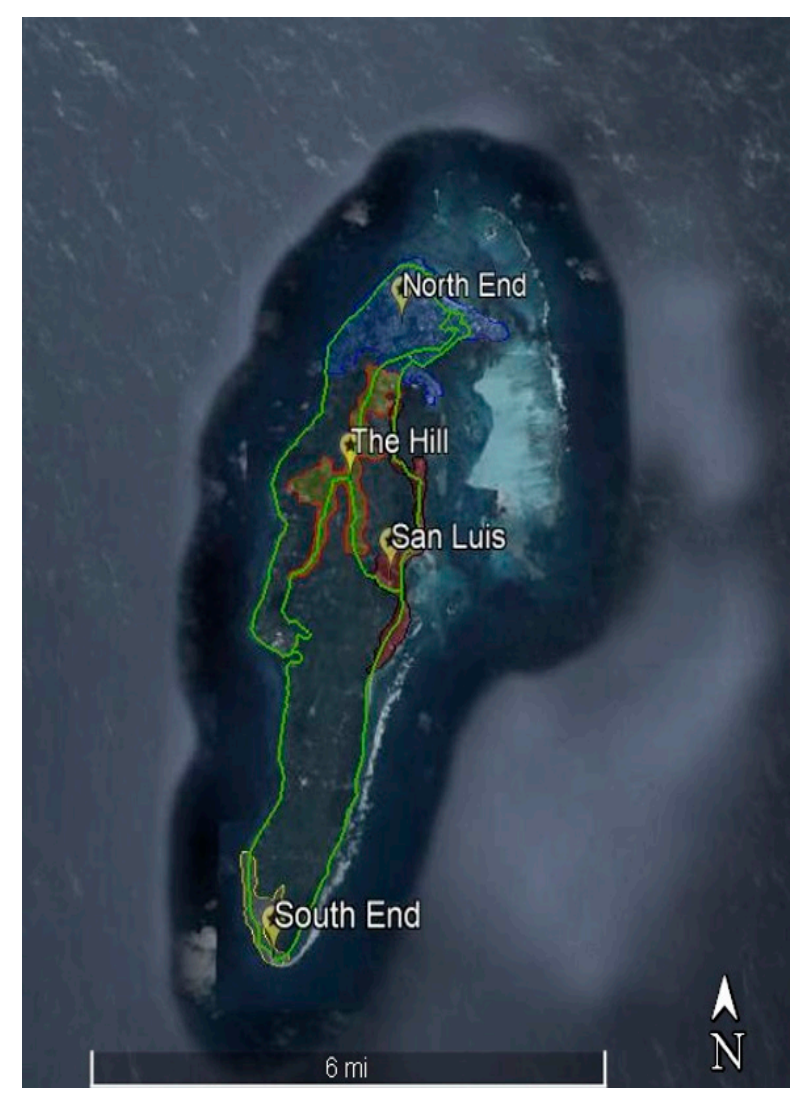

culturally and linguistically preserved. There are 56 miles of maritime waters between them, and Old Providence was not included in the expansionist commercial project of a duty-free port like San Andres. Official numbers seem to support this information with 3,970 Islander Creole speakers, accounting for $96 \%$ of the entire population, mostly living in rural areas (DANE, 2018). These rural areas are connected by the main road of the island, which surrounds the coastline, and has allowed for small settlements to form on both sides of the road.

Figure 2 shows the distribution of the Raizal population in ethnic neighborhoods around the island and the main commercial hub of Town, where the port and the mayor's office are also located. In a speech community of this size, it is safe to assume a greater maintenance of Islander Creole permeated less by the presence of Spanish in comparison to San Andres. In fact, speakers of Islander Creole in Old Providence have far fewer daily interactions with Spanish speakers, due to more rigid protective measures against new immigrants, the insistence of the locals for their English legacy (Bartens, 2013), and the value of English as the international language of tourism (Flórez, 2006). As a result, Islander is still prevalent in most aspects of the lives of Raizal communities (Moya, 2014; Bartens, 2013; Flórez, 2006; Bartens, 2002; Morren, 2001) and has helped to maintain the prestige of this Islander variety. However, fluency in Spanish is seen as a ticket to being educated in the Colombian tertiary education system thus becoming business-oriented and economically successful. Therefore, younger generations feel pressured to be balanced bilinguals in Creole and Spanish. On the contrary, most older individuals are late learners of Spanish who acquired the language in primary or middle school rather than at home. Special cases occur with some Raizal members for whom Spanish is their L1. This particularly happens when the household is constituted by one Raizal parent and the other parent was born in mainland Colombia with no knowledge of Islander Creole. The situation is even more pressing in San Andres, where the contact situation is more complex due to migratory patterns and to the economical hub that is the capital of the archipelago. As such, Raizal individuals without functional use of Islander Creole were not included in this research.

For this study, the Raizal ethnonym will be used to contrast between the Spanish varieties under examination. As noted previously, this term (raiz, meaning "root", and -al, which means "belonging to" [belonging to the root]) corresponds to the denomination of the ethnic group of the archipelago of San Andres whose genetics, history, culture, identity, and language can be traced back to their African roots. The focus of this work is the investigation of the Spanish variety spoken by generations of bilingual Raizal people. This language variety correspond to the bilingual Spanish spoken by Raizal informants, Raizal Spanish. This variety will be examined across three age-graded samples classified into 
Figure 2 Island of Old Providence with the Location of the Ethnic Neighborhoods and the Downtown Areas Highlighted (i.e., Town and Old Town)

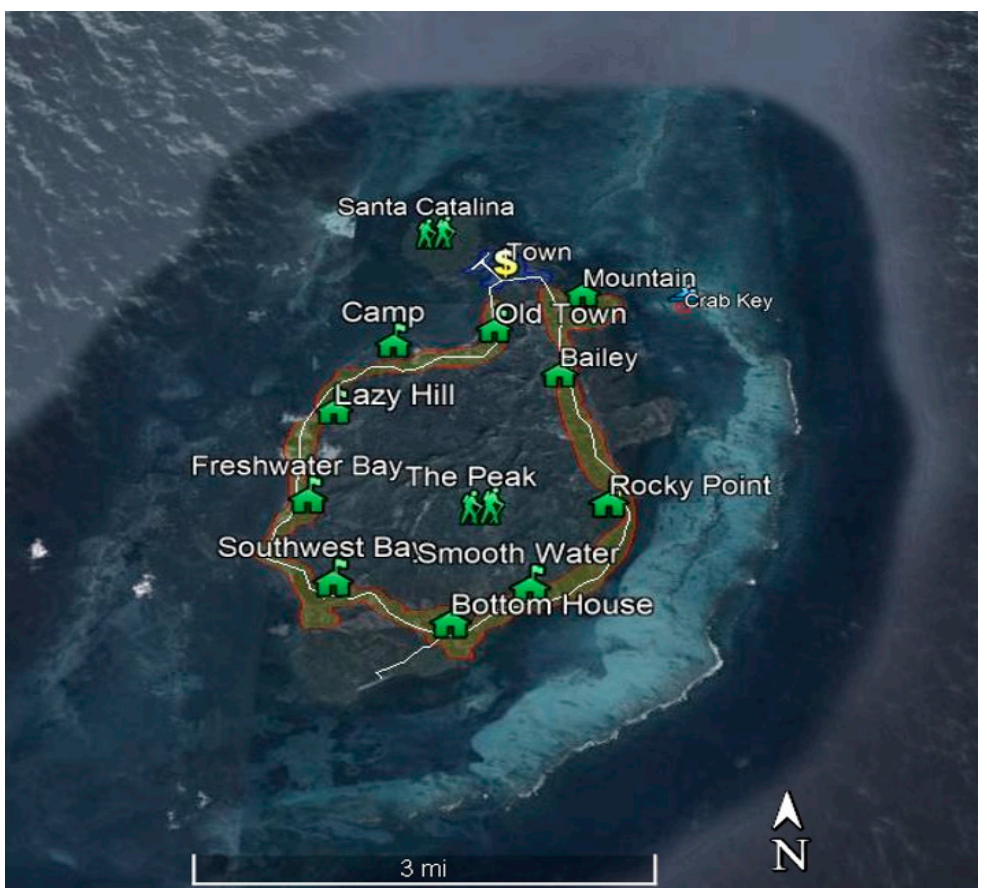

three generations of speakers in both islands of the Archipelago - San Andres and Old Providence (which includes Santa Catalina). In addition, I also compare continental Spanish, the monolingual Spanish spoken by immigrants who arrived on the islands from coastal Colombia. Therefore, the two Spanish varieties that will be examined in this study are Raizal Spanish and Continental Spanish. Raizal Spanish will be the focus of attention for this study, as the production of the tap/trill contrast will be analyzed between generations and compared with that of Continental Spanish. In addition, a preliminary crosslinguistic comparison is carried out, comparing Raizal Creole rhotics to rhotics in both Spanish varieties.

\section{Theoretical Framework}

This section presents a of review previous literature on language contact phenomena and the neutralization of the tap/trill contrast.

\section{Language Contact and the Variable Neutralization of the Tap/Trill Contrast}

A language contact phenomenon corresponds to a situation in which languages coexist within the same space and are used concurrently in the same society at the same time (Thomason, 2001, p. 1; Klee \& Lynch, 2009, p. 1). Expanding this basic definition, such conditions will imply situations of bilingualism in which anyone who uses two languages for functional purposes regardless of proficiency is considered a bilingual individual (Thomason 2001, p.3).

The development of a theory and methodology of studies on language contact have focused on the dichotomy between internal language change vs. external language change. This contrast arises from two points of view: whether we attribute a structural change (i.e., of phonological/phonetic, syntactic, morphological, etc., nature) to the gradual development of the language (i.e., internal), or to interlinguistic influence due to the (stable) 
contact between languages (external). However, both internal and external factors (i.e., sociolinguistic factors) interact in many ways to cause linguistic change and it is well accepted that this dichotomy is not mutually exclusive (Klee \& Lynch, 2009; Aikhenvald, 2006; Heine \& Kuteva, 2003; Sankoff, 2002; Thomason 2001; Silva-Corvalán, 1994; Cedergren, 1973; among others). For this reason, the interplay of multiple complex interactions from sociolinguistic factors might be in place in any language contact situation (Heine \& Kuteva, 2003).

In general terms, when we assume a linguistic feature has been an outcome of language contact, the main process of transfer is in play (Weinreich, 1953), whether direct or indirect (Silva-Corvalán, 1994). In transfer, a structural feature of a source language is simply transferred to the receiving language, producing the subsequent restructuration of the corresponding subsystems (Wienreich, 1953; Klee \& Lynch, 2009). In direct transfer, Silva-Corvalán (1994) distinguishes between substitution or incorporation of a linguistic form in the receiving language due to its use in the source language. Indirect transfer occurs from frequent use or loss of a form in the receiving language due to categorical presence or absence of another form in the source language. For this research, I use the term transfer to explain any "interlinguistic influence of structural nature," including phonological/ phonetical elements (Klee \& Lynch, 2009, p. 15).

Since age reflects historical changes in the individuals' lives (Eckert, 2017), studies on language variation have treated the concept of age as central to linguistic change (Labov, 2001). To portray evidence of stratified patterns of variation, Eckert (2017) argues that studies of age cohorts can provide evidence of real time change in progress by including age-graded samples. This technique consists of collecting samples of different individuals at different stages of life or successive points in time. In community studies, the method for selecting age groups can consist of etic or emic approaches (Eckert, 2017). The etic approach involves equal age spans (i.e., decades), while the emic approach consists of grouping individuals based on a shared experience of time, such as childhood, adulthood, etc.

The present study uses a combination of the etic and emic approaches. First, individuals were recruited as a graded-age sample due to only having access to a population of 18 years of age or older. Then, Raizal Spanish speakers were classified based on three generations, each separated by two decades: first, second, and third generation. By including these age-stratified variables, it is assumed that individuals are grouped according to sharing a particular stage of life confined in successive age cohorts. Individual speakers that share the commonality of daily life in a speech community are seen as the primary source of linguistic data for assessing language change (Labov, 2001).

The sociolinguistic patterns necessary for examining a change in progress in a speech community appear at different age and socioeconomic strata. Here, the age-graded sample obtained from three generations might reveal changes in the community. Changes from below may appear when younger speakers use less phonological features compared to the oldest group, and central-aged groups present gradual changes in a "wave-like motion" (Labov, 2001, p. 77). As the community as a whole changes rather than remaining constant (Labov, 2001), such a finding would reveal a generational change rather than age-grading stable variation apparent in time.

The bilingual speech community of the Raizal people presents a great opportunity to study the outcomes of a Creole and non-lexifier language contact phenomenon, particularly from the variable production of a phonological structure. Phonological variants are greatly susceptible to language variation and change because the properties of sounds provide speakers with a vast array of options to adapt and accommodate to social situations (Thomas, 2011). Particularly, rhotics represent a highly variable segment without a unifying physical property, since they are produced 
with different articulatory mechanisms (Thomas, 2011). Rhotics sounds are very diverse in their acoustic properties crosslinguistically and can provide a wealth of research in contact situations, especially in scenarios where the languages that coexist are lexically unrelated.

In Spanish, the realization patterns of taps and trills respond to an asymmetrical distribution based on the contextual position within the word. Taps and trills are mutually exclusive in only two positions: taps appear exclusively in complex-syllable onset positions, while word-initial contexts correspond exclusively to trills. Table 1 illustrates the general distribution of Spanish taps and trills.

Table 1 Contextual Distribution of Rhotics in Spanish

\begin{tabular}{lll}
\hline \multicolumn{1}{c}{ Context } & \multicolumn{1}{c}{ Rhotic Use } & \multicolumn{1}{c}{ Examples } \\
\hline Word Initial & Trill & /roxo/ \\
Complex Syllable & Tap & /trompo/ \\
Onset & & \\
Preconsonantal & Variable tap/trill & /barko/ or/barko/ \\
Word Medial & & \\
Word Final & Variable tap/trill & /kantar/or/kantar/ \\
Intervocalic & Contrastive tap/trill & /karo/vs/karo/ \\
\hline
\end{tabular}

Although both segments alternate in preconsonantal word-medial and word-final positions, taps generally take these positions in spontaneous speech. On the contrary, taps and trills appear in phonemic contrast in intervocalic position. This contrast is supported by around 30 minimal pairs in the Spanish language (Bradley \& Willis, 2012).

Phonetically, taps and trills are produced with similar articulatory processes but each require specific aerodynamic conditions. Ladefoged and Maddieson (1996) describe the production of a trill as the vibration of a movable part of the vocal tract placed close enough to another surface that a current of air with the right force narrowly passes through this configuration, producing the repeating closing and opening of the channel of air. When this vocal configuration produces a periodic vibration, then a trilling occurs. The Spanish language makes a distinction in the number of vibrations of the articulator (i.e., the tongue) to distinguish between two types of vibrant $/ \mathrm{r} / \mathrm{s}$. R sounds with a single short vibration are classified as taps, while longer multiple vibrations of the tongue with the upper mouth surface are known as trills. Technically, both sounds can be identified as trills, but Spanish phonemically contrasts taps and trills in intervocalic positions. However, as we will see below, the trilling feature represents more a normative distinction rather than a categorical distribution of rhotics in the Spanish language.

The opposite of a vibrant trill is a non-vibrant rhotic. These types of sounds are produced with no vibration of the articulators and are classified as either approximants (i.e., pharyngeal constriction) or fricatives (i.e., fricative noise) due to not displaying any type of occlusive phase. Based on Hammond's (1999) finding that trilling $/ r /$ production in native Spanish speakers is rare, segmental duration has been used to determine whether phonemic contrast between taps and trills is being maintained or lost in different Spanish varieties (Bradley \& Willis, 2012; Willis \& Bradley; 2008). It has been reported that the contrast between trill $/ r /$ and tap $/ r /$ can be maintained through the overall duration of both segments when no lingual closure is present in both bilingual and monolingual varieties of Spanish (Henriksen, 2015, in Chicagoland; Balam, 2013, in Belize Spanish; Bradley \& Willis, 2012, in Veracruz Spanish; Willis \& Bradley, 2008, in Dominican Spanish).

In a study of a bilingual speech community in the greater area of Chicagoland, Henriksen (2015) analyzed the potential loss of the phonological trill-tap contrast in 16 first- and second-generation Spanish-English bilinguals. He found that most of these bilinguals produce the phonemic trill either with one apical occlusion or as a non-trilled r-colored variant, potentially resulting in loss of contrast between the two Spanish 
rhotics. However, he found that almost all speakers realize the Spanish tap/trill contrast by means of segmental duration. In Belizean Spanish, Balam (2013) found that neutralization of $/ r /$ and $/ r /$ may occur in intervocalic contexts in bilingual speech production conditioned by the type of linguistic task conducted. Moreover, early language input can offset the crosslinguistic influence in bilingual speech as has been seen in simultaneous and sequential bilinguals (Cummings Ruiz \& Montrul, 2020) and even in Mandarin-English bilinguals (Chang et al., 2011). This effect of language dominance has also been attested in Spanish laterals across generations of bilinguals (Amengual, 2018). As such, it is expected that the contrast is maintained in early bilinguals that have been exposed since childhood with the Spanishonly national education system of Colombia.

In monolingual varieties, the maintenance of the tap/trill contrast has also been studied. Bradley and Willis (2012) investigated the variable production of rhotics and the correlates for the tap/ trill contrast in the Spanish of Veracruz, Mexico. They found that these variants present reduction and elision of lingual closures, but those with a measurable contact are produced long enough to be measured in terms of segmental duration. Overall, trills are produced in this variety with one or two lingual contacts with a pre or postapproximant phase, and taps are produced with no visible contact in most cases. These findings resonate with an earlier study on Dominican Spanish (Willis \& Bradley, 2008) that reveal the contrast maintenance of taps and trills according to durational cues. A great deal of non-trilled realizations in Central American Spanish and certain Colombian Spanish varieties have been documented, suggesting that multiple-contact trills are rare in general. In a survey of rhotic production in Central and South American Spanish varieties, Bradley (2006) found that only 16\% of syllable-initial tokens in / $\mathrm{sr} /$ clusters across word boundaries could be classified as trills (containing two lingual closures), and only one token presented the prescribed three lingual-contact closure. Colombian informants realized non-trilled variants in a 4 to 1 proportion compared to normative trills. From these, $60 \%$ percent constituted approximant realizations and another $20 \%$ fricative rhotics. We must note that the informants selected for this study exhibited zero /s/ reduction in post nuclear position, which differs from the description of the vast lowland immigrant residents in the Archipelago of San Andres. Fricative realizations of rhotics in syllable-initial position have also been documented in the central highlands of Colombia conditioned by sociolinguistic factors (Lipski, 1994).

In sum, non-vibrant rhotics are a widespread phenomenon that has even been characterized as a change in progress in the Spanish language (DiazCampos, 2008; Henriksen, 2014). Non-vibrant rhotics have been attested in monolingual Spanish varieties, including the Spanish of Corrientes, Argentina (Colantoni, 2006), Peninsular Spanish (Zahler \& Daidone, 2014; Hammond, 1999; Henriksen \& Willis, 2010), Ecuadorian Spanish (Bradley, 1999), Peruvian Spanish (Díez-Canseco, 1997), Costa Rican Spanish (Lipski, 2011), and Mexican Spanish (Lastra \& Buitragueño, 2006). This is because the production of a vibrant trill is complex. Spanish rhotic articulation requires specialized articulatory gestures and aerodynamic conditions to produce a prototypical trill. These conditions include a stable apico-alveolar closure with more apical retraction and predorsum lowering than the tap (Recasens \& Pallares, 1999). Solé (2002) also notices that trills require higher pressure build-up, greater magnitude of linguo-palatal contact and longer duration of the first closure to be produced (p. 686). According to this author, small variations in oral pressure result in no trilling or devoicing.

What is relevant in these studies is that monolingual and bilingual speakers' maintenance and neutralization of the tap/trill contrast has been attested and that segmental duration has been used as a reliable 
measurement, perceptible enough to distinguish between taps and trills in monolingual and bilingual communities. In this sense, a study on the perception of non-vibrant $/ \mathrm{r} /$ has shown that the contrast is perceptually distinguishable in terms of durational values, which aligns with the maintenance of the tap/trill contrast (Melero-García \& Cisneros, 2020). The analysis of cross-generational differences will show whether the prototypical contrast is maintained or neutralized, which may suggest variation in the articulation of rhotics in this contact scenario where a Creole is in contact with a national non-lexifier language (Aceto, 1999; Snow, 2000). Precisely, the bilingual variety of Raizal Spanish has been observed to present non-vibrant, intervocalic tap/trill variants. Figure 3 shows two examples of intervocalic tap and trill produced with zero occlusion and their corresponding duration.

As seen in Figure 3, there is a 20-millisecond difference between the length of the tap and that of the trill, which demonstrates the close approximation in segmental duration of both components. Both phones appear to be realized with an approximant manner of production as an alveolar tap and a postalveolar trill. Moreover, both segments are produced by speakers of the same older generation. However, the extent to which this is generalizable across age groups, which would signal a change in progress, is yet to be studied. Therefore, in this study, I examine the duration of word-medial, intervocalic taps and trills in Raizal Spanish to determine cross-generational production differences and the maintenance or neutralization of tap trill differences. Likewise, segmental duration in Islander Creole rhotics was also measured to compare between the languages of the archipelago. As it has been noted previously, Islander Creole produces a post-alveolar approximant with different tongue postures for retroflex and bunched-tip variants (Restrepo-Ramos, 2019).

This preliminary crosslinguistic comparison will serve as a reference point to shed light on the segmental differences between non-vibrant rhotics in an English-based Creole and Spanish. While Creole rhotics are measured in all contexts, for the sake of crosslinguistic comparison, I focus on taps and trills only when comparing both varieties of Spanish: Raizal and Continental. Moreover, in order to test the hypothesis that the contrast of taps and trills is suited for neutralization across generations of bilinguals, it is of special interest to check whether stress has an effect on the trill/tap contrast in intervocalic approximant rhotics. Due to the articulatory emphasis employed in stressed

Figure 3 Samples of Non-Vibrant Rhotics in First-Generation Raizal Spanish Speakers
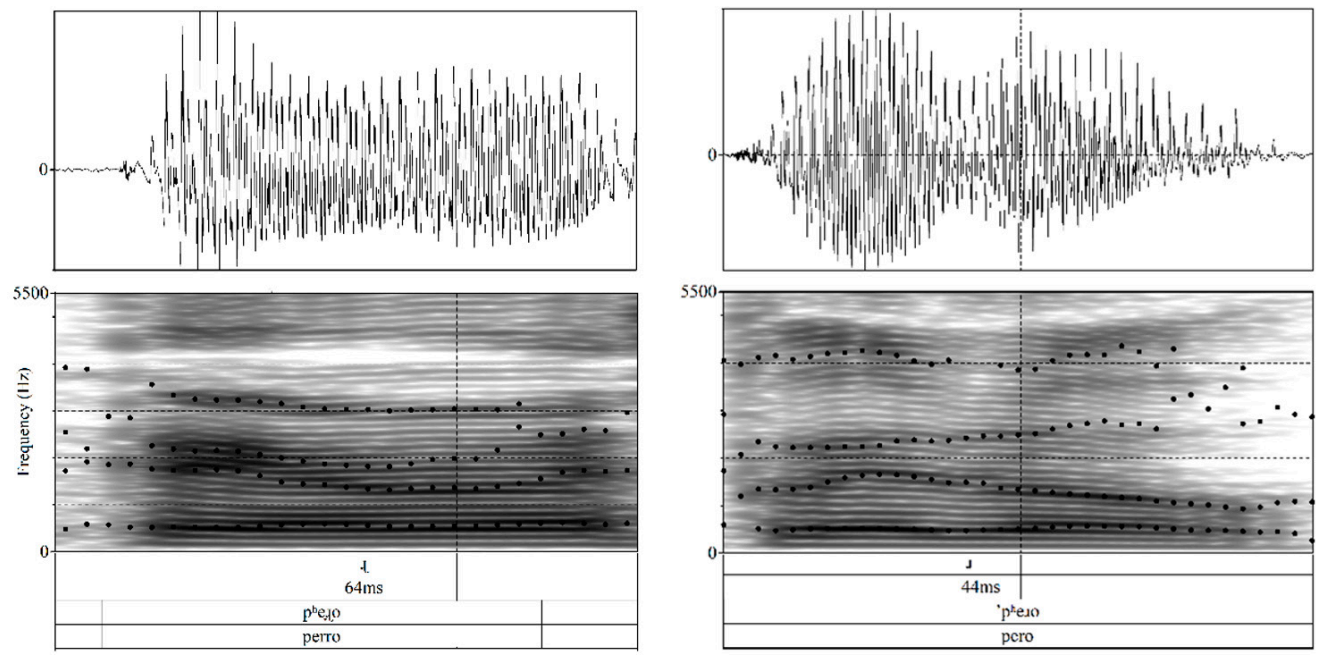

Note: (Left) Non-vibrant trill in the word perro ( $\mathrm{dog}$ ) with a duration of $64 \mathrm{~ms}$. (Right) Non-vibrant tap in the word pero (but) with a duration of $44 \mathrm{~ms}$. Segments are produced by first-generation Raizal Spanish speakers. 
syllables, rhotics in these contexts might be produced with a higher production effort, and thus, longer segmental duration.

The analysis of segmental duration for non-vibrant approximant rhotic segments has implications for the classification of Spanish non-vibrant trills and taps and for the outcomes of contact in this Spanish variety (Thomason, 2020). While the erosion of durational differences between taps and trills might signal articulatory processes and phonological categorization involved in sound production, cross-generational differences would indicate a potential change in the contrast of these sound segments. Meanwhile, a further comparison with the monolingual Continental variety will elucidate whether any Raizal generation is gradually converging toward the direction of Spanish.

It is hypothesized that younger generations of Raizal individuals are converging towards Continental Spanish, while older generations present variation from the Spanish norm, resulting in the extreme case of neutralization of the tap/trill contrast. Such results would indicate a possible ongoing change in progress of the tap/trill contrast in the Archipelago of San Andres. The analysis of the tap/trill contrast in Raizal Spanish presents a novel approach to study the current situation of language contact in the Caribbean Archipelago of San Andres.

This empirical research aims to answer two research questions narrow in scope. First, are there durational differences between non-vibrant taps and trills in the Spanish varieties? If so, are there any generations of Raizal Spanish speakers that neutralize the tap/trill contrast based on word stress? The answer to these pertinent questions will allow us to examine in detail the outcomes of contact between an English-based Creole and Spanish as a national language in the Western Caribbean.

\section{Method}

Data for this study were collected during the span of three weeks in the Archipelago of San Andres, Colombia, namely on the islands of
San Andres and Old Providence. Speech data were obtained from bilingual Raizal informants through sociolinguistic interviews eliciting background information and covering topics of interest to the Raizal community (e.g., current social, ethnic, and territorial issues, work, family, everyday life, etc.). Recordings took place in noncontrolled environments, such as the dwelling of the informants, although effort was taken to minimize background noise. For each recording, a digital recorder sampled at $44100 \mathrm{~Hz} / 32$-bit was used as well as an omnidirectional lavalier microphone with a mounted preamplifier, and a frequency response of 80 to $20,000 \mathrm{~Hz}$ was placed as close to the mouth as possible. In order to examine the potential process of sound change in Raizal Spanish, speech data from 30 island-born, Creole-natives Raizal informants were collected with ages ranging from 18 to 89 . The concept of age has been a topic of discussion in the literature.

Eckert (2017) argues that studies of age cohorts based on age-graded samples can unequivocally show change at different life stages. The sample for this study consists of successive age cohorts separated into three generational age groups. Care was taken to have a balanced number of informants. Ten informants per age group were recruited. The different age groups were selected based on the median age per generation with almost 20 years difference. In total, 1450 non-vibrant rhotic tokens were surveyed. From these, 619 Praat-annotated word-medial, intervocalic tap/ trill tokens were sampled (Boersma \& Weenink, 2020), accounting for 505 taps, and 114 trills. Each token was obtained from a transcribed sample of 15 minutes of speech selected 15 minutes after initiating the recording. Table 2 shows the distribution of the informants based on generation, age, sex, and tap/trill production.

As seen in Table 2, three generations are distinguished in Raizal Spanish, all of which are separated by 20 years on average. In terms of production rates, taps were realized more frequently 
Table 2 Background Information and Tap/Trill Production Across Generations of Raizal Informants

\begin{tabular}{|c|c|c|c|c|c|c|}
\hline Generation & Age Median & Age Range/Mode & Sex & Tap & Trill & Tap/Trill Ratio \\
\hline $1^{\text {st }}$ Generation & 67 & $58-89 / 66$ & 6 females, 4 males & 228 & 46 & $1: 0.20$ \\
\hline $2^{\text {nd }}$ Generation & 44.5 & $36-49 / \mathrm{NA}$ & 6 females, 4 males & 164 & 54 & 1:0.31 \\
\hline $3^{\text {rd }}$ Generation & 27 & $18-34(34)$ & 4 females, 6 males & 113 & 14 & $1: 0.12$ \\
\hline
\end{tabular}

than trills across all generations in the datasets. These non-vibrant taps and trills were identified according to the absence of occlusion in the spectrogram, including the abrupt changes in the waveform and uninterrupted fluctuations in the formant structure. Further acoustical cues facilitating rhotic identification and labeling included the relative low onset of F3 frequencies and formant transition between liquids and r-coloring of contiguous vowels (Bradley \& Willis, 2012; Kent \& Read, 2002; Morgan \& Sessarego, 2016). For the sake of the homogeneity of the samples, weakened trills presenting one occlusion and an approximant phase were omitted from the analysis. Figure 4 shows two examples of token labeling and annotation in Praat.

Based on this classification criteria, each segment was inspected and annotated in the Textgrid. Subsequently, a Praat script for the automatic extraction of segmental duration was used (Lennes, 2002). Measurements were entered on a spreadsheet and each token was coded based on the type of production (i.e., tap or trill), position of the segment in the word relative to the stressed syllable (i.e., pre-tonic, tonic, and posttonic), preceding and following vowel, number of syllables in the word, grammatical category (e.g., noun, verb, etc.) and generation. For this analysis, only type of production (either tap or trill), stress, and generation are analyzed. The coded dataset was submitted to $\mathrm{R}$ for statistical analysis and data visualization (Team, 2013). The statistical analysis consisted of a mixed effects model for testing the relationship of durational differences and word stress.

Additionally, speech data from eight monolingual Continental Spanish speakers were collected. Tokens from these data were combined with those from Raizal Spanish with the aim of comparing the durational properties of non-vibrant rhotics in

Figure 4 Token Labeling and Annotation in Praat for both Taps and Trills in Raizal Spanish
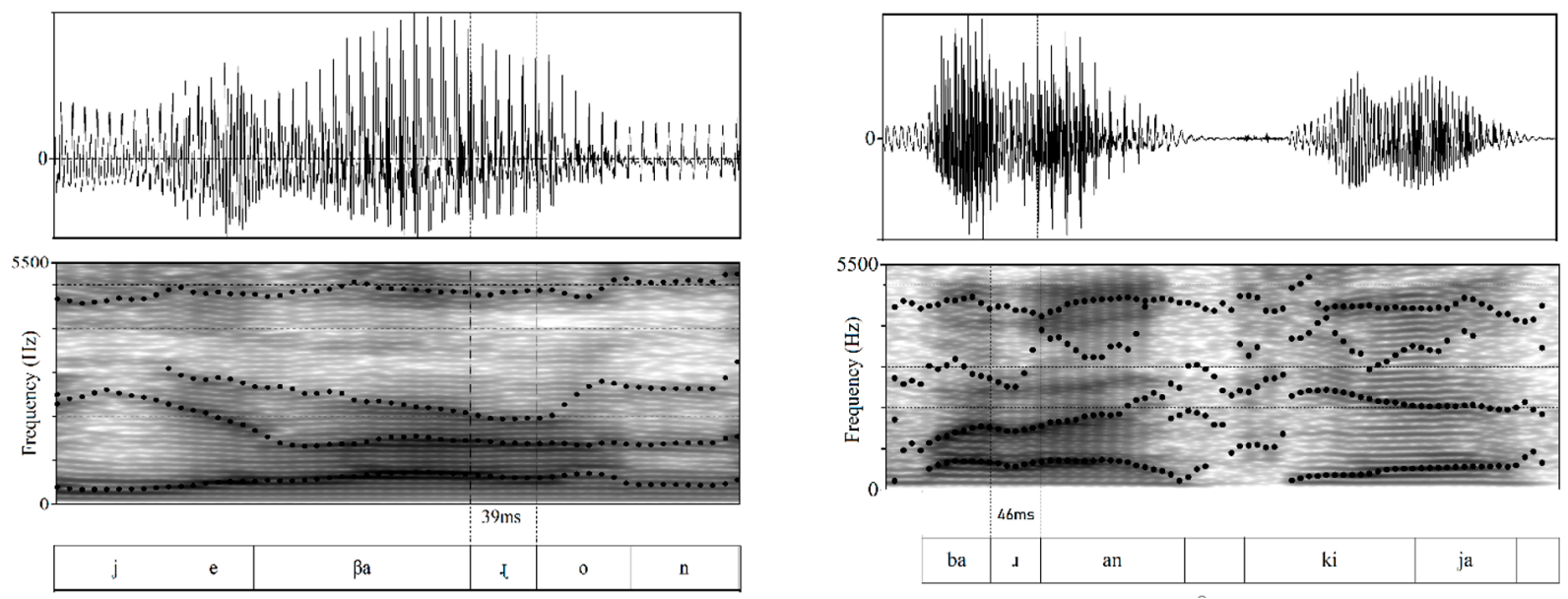

Note: (Left) Intervocalic tap presenting no visible occlusion and labeled based on abrupt changes in the waveform, formant transition, and F3-F2 narrowing. (Right) Intervocalic trill classified according to changing formant structure, lowering of F3, and decreasing amplitude of the waveform. 
Spanish and in Islander Creole. For this comparison, 64 intervocalic tokens were extracted (i.e., 57 taps and 7 trills) from a sample of 150 non-vibrant rhotics in Contintental Spanish and summed to the 619 tokens of Raizal Spanish described above. Likewise, 328 rhotic samples were collected from Islander Creole and annotated in Praat in order to conduct a crosslinguistic comparison between Spanish (Continental and Raizal) and Islander Creole. For this additional analysis, speech data were collected from five Raizal informants, who were asked to narrate the frog story in Creole (Mayer, 1969) or recount Anansi stories (traditional folk stories from the Gold Coast in Western Africa). The same coding schema as for the Raizal Spanish data set was used, but no generational groups were considered due to the low number of participants.

I distinguish two methods for the analysis of the segmental duration of the non-vibrant rhotics of the archipelago. First, I present an overall comparison of segmental duration between varieties (i.e., Islander Creole, Raizal Spanish, and Continental Spanish). Since this first overall comparison contrasts between varieties, no distinction between trills and taps are made. Then, I compare the two Spanish varieties, Continental Spanish and Raizal Spanish, in terms of segmental duration between trills and taps. By doing this, I test for a potential change in progress based on word stress relative to rhotic position. I now present the results of these analyses in the following section.

\section{Results}

This section presents the results of the comparative analysis of rhotic duration in the varieties of the archipelago and the tap/trill contrast across generations of Raizal Spanish. The first comparison shows the overall duration of rhotic segments in the varieties of the archipelago, including Raizal Spanish, Continental Spanish, and Islander Creole. Next, I compare the segmental duration in non-vibrant taps and trills between Raizal and Continental Spanish.

\section{A Crosslinguistic Comparison of Rhotic Duration in the Archipelago}

It is worth noting that Islander Creole makes no phonemic distinction between tap and trills compared to Spanish, and thus, this comparison between varieties might reveal significant differences across all word contexts, including intervocalic positions. As a result, this comparison serves the purpose of exploring general patterns of segmental duration across linguistic varieties. Figure 5 displays the mean durations of approximant rhotics in the archipelago.

Overall, Islander Creole presents higher mean durations for rhotic realizations. In contrast, Raizal Spanish seems to be associated with the Continental variety with a difference of $0.0104 \mathrm{~ms}$ compared to the mean distance with Islander Creole $(0.0378 \mathrm{~ms})$. The monolingual Spanish variety shows shorter segmental duration for rhotics in all contexts. Now, when we look more closely into these differences in terms of word context, we find that these linguistic varieties vary according to the position in the word. For this comparison,

Figure 5 Boxplot with Mean Values for Segmental Duration in all Varieties and Word Contexts

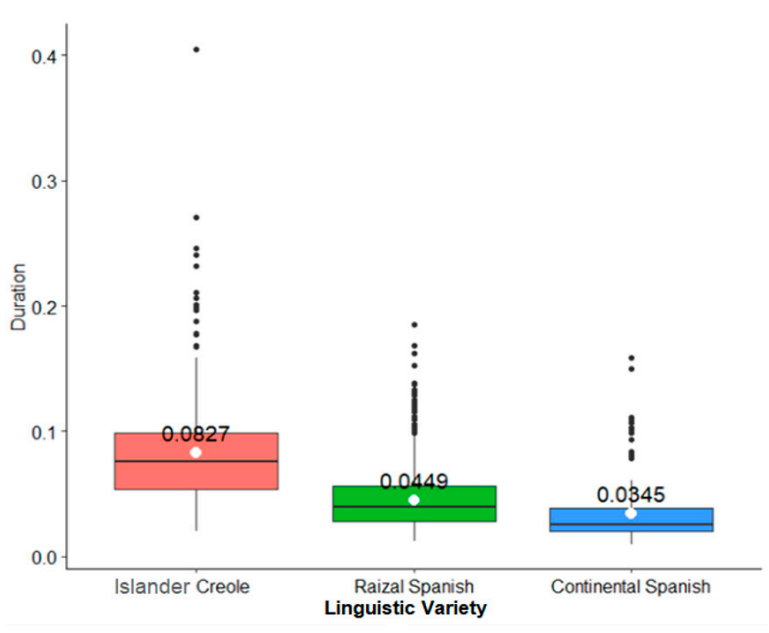


Figure 6 Mean Duration in Milliseconds Across Population Groups and Position of the Rhotic within the Word

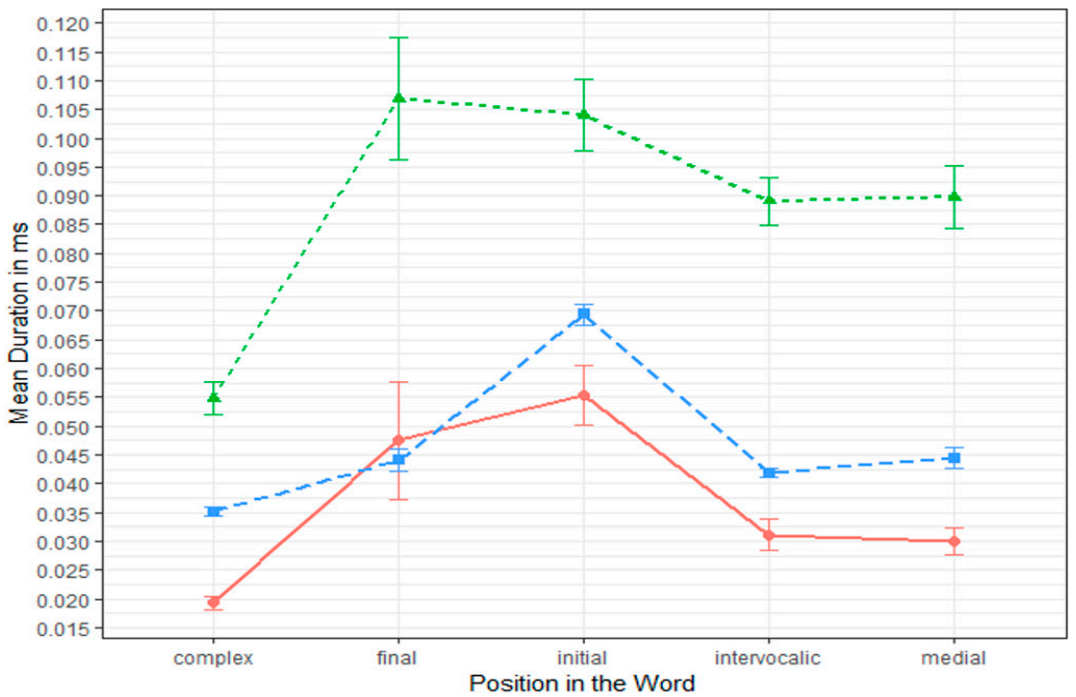

five word positions are contrasted in Spanish and Creole: complex syllabic onsets (i.e., precio [price] and treza [treasure]), word final (i.e., mar [sea] and kyar [car]), word initial (i.e., rosa [rose] and rak [rock]), intervocalic (i.e., perro $[\mathrm{dog}]$ and araun [around]), and preconsonantal, word medial (i.e., marzo [March] and baarn [burn]).

As seen in Figure 6, duration of the rhotic segment is dependent upon word context and language. For instance, Islander Creole has longer segmental duration in all positions within words, while Spanish, either the Raizal or the Continental variety, behaves with similar patterns across different word contexts. In general, rhotics used in complex onsets present the shortest durations in Continental Spanish, Raizal Spanish, and Islander Creole, ranging from $19 \mathrm{~ms}$ and $35 \mathrm{~ms}$ to $55 \mathrm{~ms}$, respectively. In contrast, approximant rhotics in initial position have the longest duration in the Spanish population groups, and the second longest segment in Islander Creole.

Visually, non-vibrant rhotics in intervocalic positions present the second shortest duration in most varieties except in Continental Spanish, which presents one of the shortest durations right before medial positions. It has been reported that Spanish trills have a duration ranging from 60 to $90 \mathrm{~ms}$ (Henriksen, 2015; Bradley \& Willis, 2012), considerably higher than the approximants reported here. The differences in duration suggest different articulation processes in the aerodynamic conditions that support the trill realization and the subsequent lingual closures that ensue. Solé (2002) showed that specific aerodynamic conditions need to be met in order to maintain the appropriate air pressure to produce the voiced trills. Any variation in the magnitude of 2.5 to $5 \mathrm{~cm}$. "impaired voiced and voiceless trills" (p. 686). Any larger drop of the oropharyngeal and subglottal pressure will result in an approximant realization (p. 682). Thus, the articulatory gestures to attain a tongue-tip trilling require precise aerodynamic conditions and lingual positionings that contrast with the conditions present in an approximant allophone.

These aerodynamic conditions partly explain the differences in mean durations in intervocalic position between the Spanish approximants in the archipelago. The longer durations for Islander Creole rhotics seem to be language-specific, a pattern that Raizal informants seem to fully differentiate. Despite appearing with longer durations across all word contexts (except for word-final positions), segmental durations in Raizal Spanish 
are approaching Continental Spanish rather than diverging towards Islander Creole. Final-word contexts in both Spanish varieties are the only position that follows a different pattern than Islander Creole. There is also greater variability in this context as illustrated in the standard error bars. Figure 7 shows the contrast between coarticulation of the vowel segment and the abrupt segmentation of the contiguous stop consonant in Islander word-final rhotics.

Although final-word contexts are the second longest in both varieties of Spanish, Islander Creole presents the greatest differences in segmental duration in this position. A closer inspection of the data revealed that over $28 \%$ and $21 \%$ of word-final rhotics in Creole were followed by a consonant and a pause, respectively, with an average duration of $91 \mathrm{~ms}$. Conversely, $50 \%$ of word-final rhotics were followed by vowel with an average duration of $81 \mathrm{~ms}, 10$ milliseconds shorter in average compared to the previous contexts. This difference in mean duration is due to coarticulation with the preceding vocalic element, where the / $\mathrm{r}$ / segment boundaries become indistinguishable through a smooth sequence. It is worth noting that all consonantal elements following the word-final approximant consisted of obstruents (i.e., / $\mathrm{d} \mathrm{m} \mathrm{p/}$ and $/ 3 /$ ), segments that have a distinctive abrupt transition in the formant frequency visible in the spectrograph, due to occlusive phases and noise.

These differences in the nature of contiguous elements might explain the greater variability in segmental duration in final-word position due to being the only position permitting either a contiguous pause or a stop consonant. Therefore, visible formant transitions and longer and distinguishable rhotic sounds are present in this word position. Likewise, this particular word context displays highly frequent cases of non-rhoticity and thus one of the contexts most permeable to rhotic erosion. It is possible that Creole speakers have two distinct allophonic realizations in this position: One that requires additional articulatory effort and thus more duration and a contrastive production that can either merge or coarticulate with the preceding vowel transforming itself into a shwa-like vowel (Zhou et al., 2008).

Figure 7 Spectrogram of Word-Final Rhotic in Islander Creole with Different Contiguous Elements
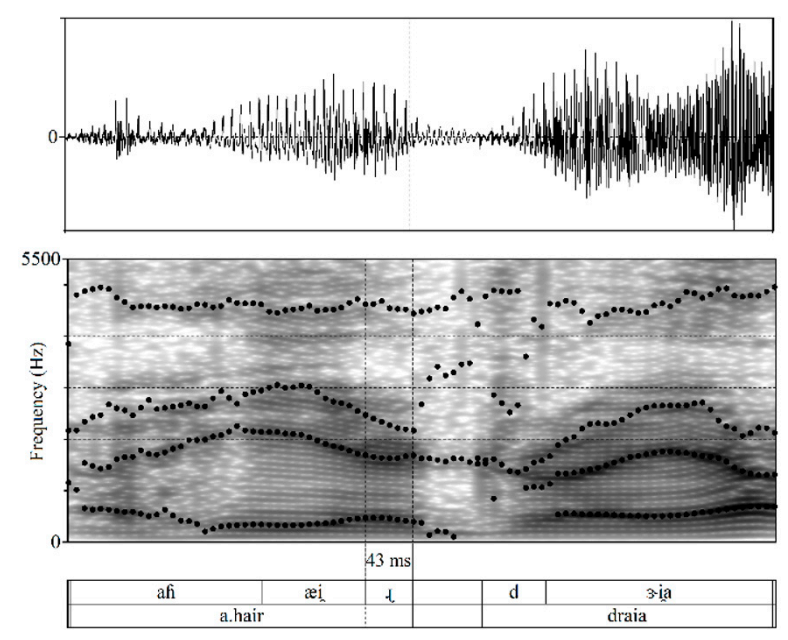

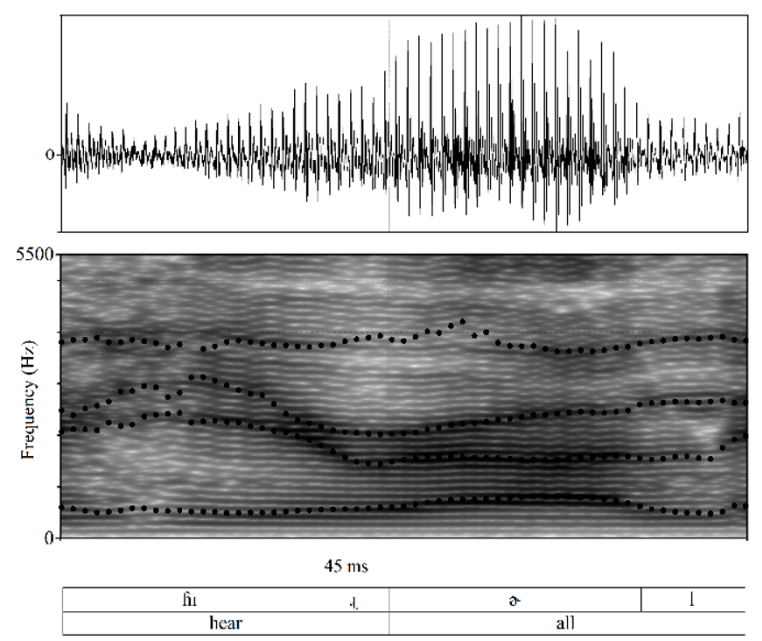

Note: (Left) / r/ followed by a stop consonant and the abrupt end of the formant frequency lines. (Right) Coarticulation of $/ \mathrm{r} /$ with the contiguous vocalic element. Note the continuation of the formant lines until F3 and F2 begin to separate some 0.034 milliseconds later. 
In terms of segmental duration differences according to word stress, Figure 8 shows rhotic duration in three stress categories relative to rhotic position in the word: tonic (i.e., [a.'ros] rice), pre-tonic (i.e., [ba.ran.'ki.ja] Barranquilla), and post-tonic (i.e., ['pe.ro] dog).

Language differences appear between the Spanish varieties and Creole, where Islander contrasts with the Spanish varieties, shown by its higher duration in all stress contexts, particularly in posttonic rhotics, while the Spanish varieties appear in the opposite spectrum. Pre-tonic rhotics have the shortest duration in Islander Creole but one of the highest in both Raizal and Continental Spanish. As expected, these two varieties of Spanish seem to have the same rhotic duration patterns in terms of word stress although Raizal Spanish presents longer overall durations. In general, pre-tonic and tonic rhotics have the same duration pattern in Spanish and a preference for shortest post-tonic durations. Despite the longer rhotic duration across stress categories, Raizal Spanish shares similar duration measurements to the monolingual variety and appears to approach the Continental Spanish in all stress contexts. The only exception appears in tonic position due to a slightly longer duration compared to Continental Spanish, a pattern also found in other monolingual Spanish varieties (Colantoni, 2006, for Corrientes Spanish, Argentina). While Islander has longer durations in post-tonic rhotics and shorter durations in pre-tonic and tonic positions, Spanish prefers shorter durations in post-tonic rhotics and longer segments in pre-tonic and tonic positions.

In sum, we can see that Islander Creole and Spanish differ on the overall segmental duration of their approximant rhotics. Longer rhotic segments are found in Islander Creole while Spanish has shorter versions. These differences are also evident in terms of word context and word stress. The varieties of the archipelago produce contrastive rhotic durations in word-initial and complex onset contexts and in post-tonic positions. I now turn to a comparison of trill/tap durations between Raizal Spanish and Continental Spanish. This is done to examine the neutralization of the tap/trill contrast

Figure 8 Differences in Mean Rhotic Duration Based on Word Stress Across the Varieties of the Archipelago

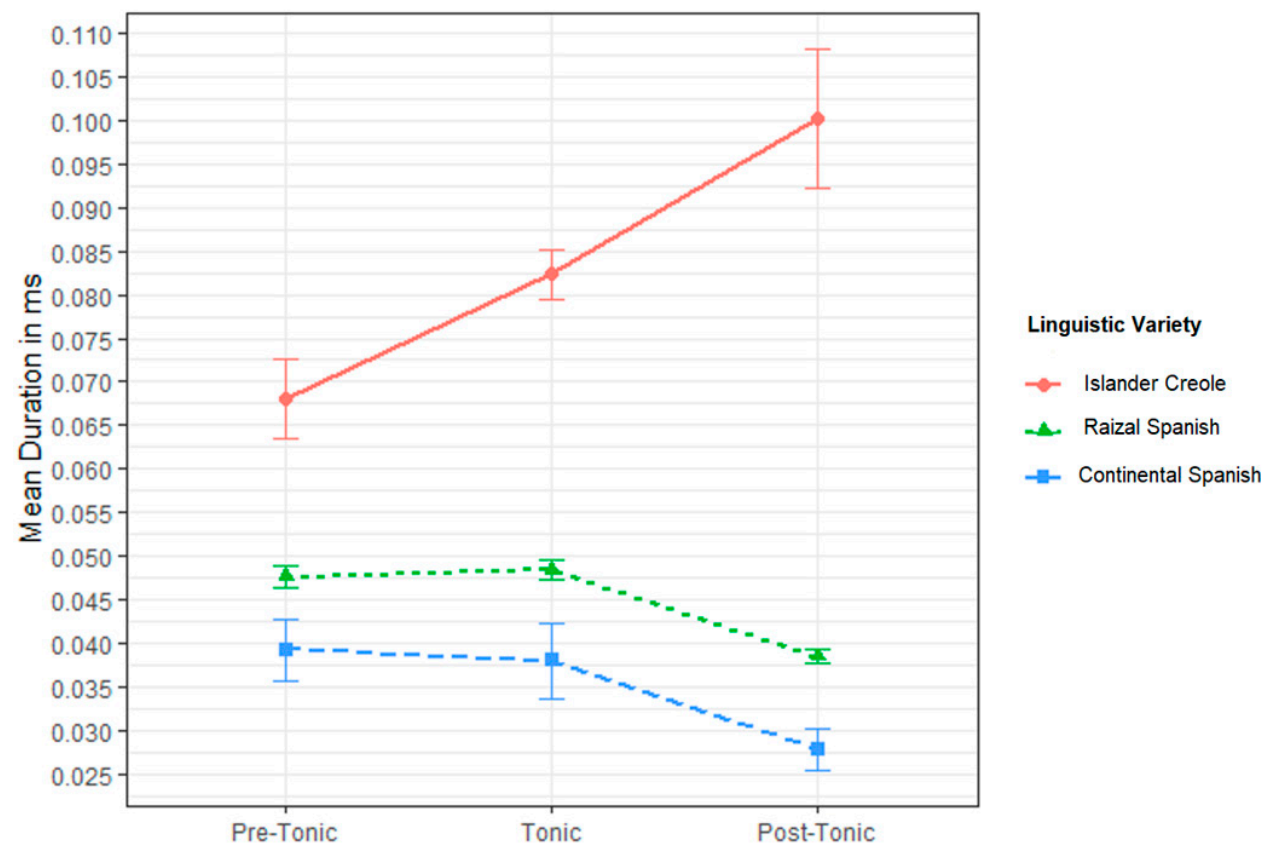


Figure 9 Tap/Trill Contrast in Continental Spanish and Raizal Spanish

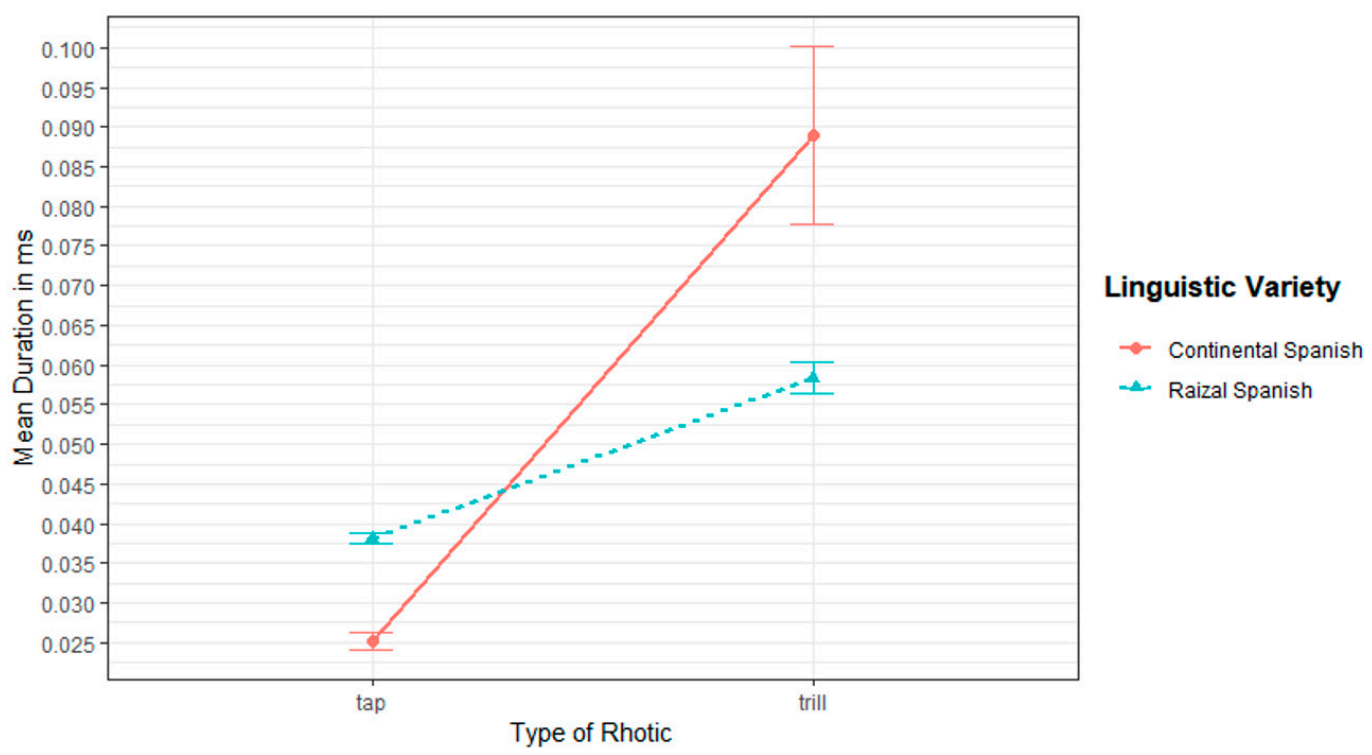

that might be affected by stress in the two Spanish varieties of the archipelago.

\section{A Comparison of Segmental Duration of Non-Vibrant Taps and Trills Between Raizal and Continental Spanish}

In this section, Continental Spanish and Raizal Spanish are compared in terms of the duration of the approximant rhotics that present no vibration in their respective contrastive context: intervocalic, word-medial position (i.e., carro [car] vs caro [expensive]). In this study, no instance of a syllable-initial, word-internal tap that contrasted with a trill in this position was found ${ }^{2}$. A comparison of the tap/trill contrast between the bilingual and monolingual Spanish varieties is presented in Figure 9, where the mean duration of tap and trills are contrasted in both Spanish varieties.

As seen in Figure 9, Continental Spanish defines the boundaries between taps and trills with a visible contrast in duration. Raizal Spanish uses the

2 In some instances, a word-initial trill may contrast with a syllable-initial tap in word internal position (a Roma 'to Rome' vs aroma 'aroma') (Hualde, 2005, p. 183, in Henriksen, 2015). same durational cues to contrast between taps and trills, but this effect seems to be weaker compared to the monolingual variety. Although these intervocalic rhotics present duration differences in both Spanish varieties, Raizal Spanish shows closer duration values between taps and trills compared to Continental Spanish. In other words, Continental Spanish seems to make use of segmental duration to successfully contrast between approximant taps and trills in intervocalic position, while this contrast seems less clear in Raizal Spanish. Based on this interpretation, a comparison of the segmental duration of non-vibrant taps and trills in Raizal Spanish is warranted in order to determine whether there is neutralization of the tap/trill contrast in the bilingual Spanish variety. A subsequent visualization of segmental duration across generations of Raizal bilinguals gives further detail about the differences in rhotic variation in this population. This is seen in Figure 10 , where the values for segmental duration of Spanish taps and trills are visualized.

Figure 10 shows that mean duration values in bilingual Raizal Spanish seem to fluctuate across age groups. The closer distance between taps and trills appears in the first generation ( $41 \mathrm{~ms}$ for taps and $57 \mathrm{~ms}$ for trills), while the third generation 
Figure 10 Mean Duration of Approximant Taps and Trills in Intervocalic Position in Raizal Spanish by Generation

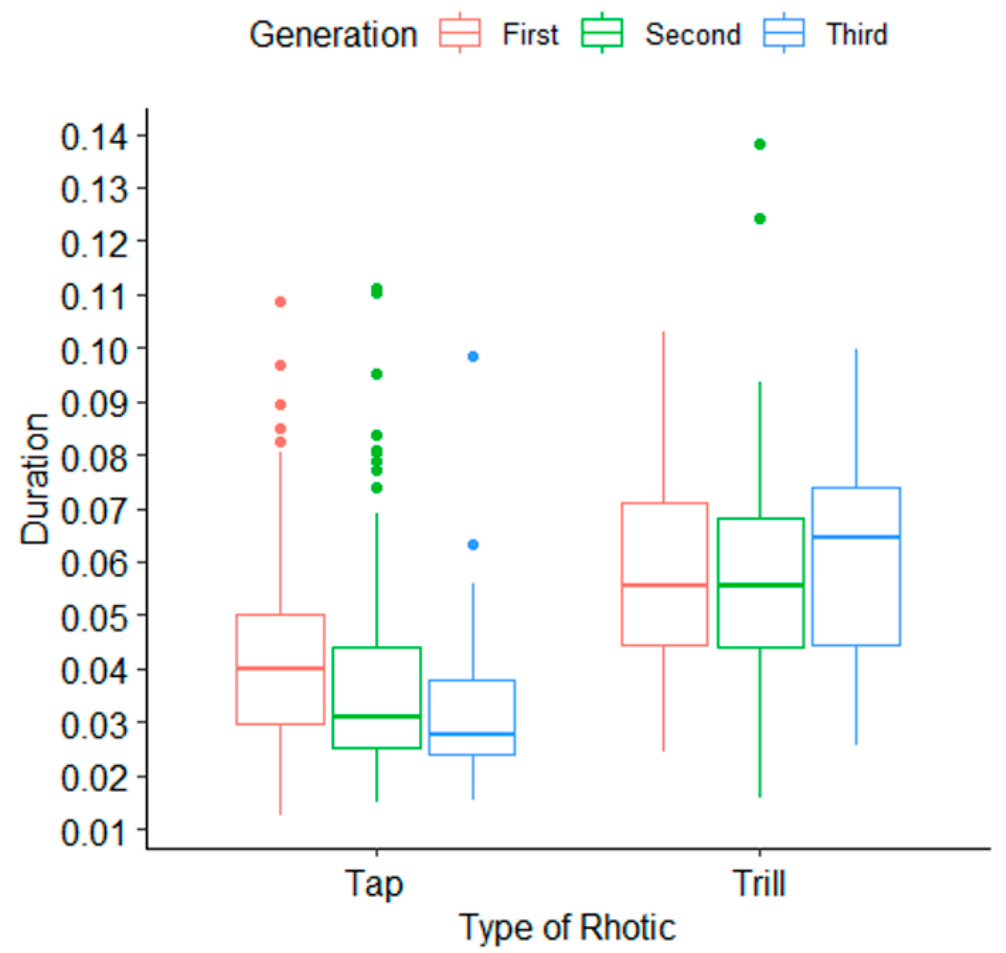

presents a greater mean distance between both segments ( $32 \mathrm{~ms}$ for taps and $60 \mathrm{~ms}$ for trills). The second generation displays intermediate mean values between both first and third generations (37 $\mathrm{ms}$ for taps and $58 \mathrm{~ms}$ for trills). However, segmental duration in bilingual taps and trills presents a great deal of variability, as there are certain taps that appear with duration values that approximate trills in first and second generation rhotics. This seems to hint at a possible neutralization of taps and trills in specific contexts in these generations. On the contrary, there seem to be clearer differences and less variation in third generation Raizal individuals. In order to test the hypothesis that the contrast of taps and trills is permeable to neutralization across generations of bilinguals, it is of special interest to check whether stress has an effect on the tap/trill contrast in intervocalic approximant rhotics. As noted previously, due to the articulatory emphasis employed in stressed syllables, rhotics in these contexts might be produced with a higher production effort and thus longer segmental duration. Table 3 summarizes the duration values of rhotics in intervocalic position according to word stress. Specifically, pre-tonic refers to the tap/trill occurring prior to the tonic syllable while post-tonic denotes the tap/trill occurring after the tonic syllable.

While post-tonic rhotics have the highest count, they have the lowest mean duration (0.03905s). Conversely, tonic rhotics present the longest duration $(0.05039 \mathrm{~s})$, and pre-tonic rhotics appear with a mean duration of 41 milliseconds. These mean duration differences and the fluctuation in

Table 3 Intervocalic Rhotics in Raizal Spanish According to Word Stress Relative to Rhotic

\begin{tabular}{lcccc}
\hline \multicolumn{1}{c}{ Stress } & Mean & SD & N & SE \\
\hline Pre-tonic & 0.04174 & 0.01775 & 53 & 0.00244 \\
Tonic & 0.05039 & 0.02316 & 142 & 0.00194 \\
Post-tonic & 0.03905 & 0.01673 & 424 & 0.00081 \\
\hline
\end{tabular}


Table 4 Intervocalic Taps and Trills in Raizal Spanish Based on Rhotic Stress

\begin{tabular}{cccccc}
\hline Trill/Tap & Stress & Mean & SD & N & SE \\
\hline Tap & Pre-tonic & 0.03717 & 0.01652 & 38 & 0.00268 \\
Tap & Tonic & 0.04381 & 0.02007 & 102 & 0.00199 \\
Tap & Post-tonic & 0.03667 & 0.01477 & 365 & 0.00077 \\
Trill & Pre-tonic & 0.05333 & 0.01574 & 15 & 0.00406 \\
Trill & Tonic & 0.06717 & 0.0222 & 40 & 0.00351 \\
Trill & Post-tonic & 0.05374 & 0.02042 & 59 & 0.00266 \\
\hline
\end{tabular}

the standard deviation throughout all stress contexts suggest that segmental duration in taps and trills might be conditioned by word stress. Table 4 compares mean duration differences between taps and trills according to syllabic stress.

Overall, mean duration times appear shorter in taps than in trills as seen on Table 4, which at first sight, shows that Raizal bilinguals contrast between these two phonemic rhotic phonemes. However, standard deviation measurements show that duration in taps through all word stress contexts vary to a degree that approximates trills. Similarly, Figure 11 graphically displays these duration differences in terms of word stress.
Both taps and trills show the same pattern of stress variation where pre-tonic and post-tonic rhotics appear with similar duration. In contrast, tonic contexts display the highest duration values in both taps and trills. It seems that, if neutralization of the tap/trill contrast exists, tonic taps and pre-tonic trills might be approaching each other, because they show overlapping duration values. Precisely to determine the nature of segmental durations in taps and trills according to word stress, a mixed effects test was conducted to examine the interaction effect between the type of rhotic (i.e., taps and trills) and stress in segmental duration. This test is ideal for sociolinguistic research due to the low sample size we have. Moreover, it will

Figure 11 Duration of Intervocalic Rhotics in Raizal Spanish According to Word Stress

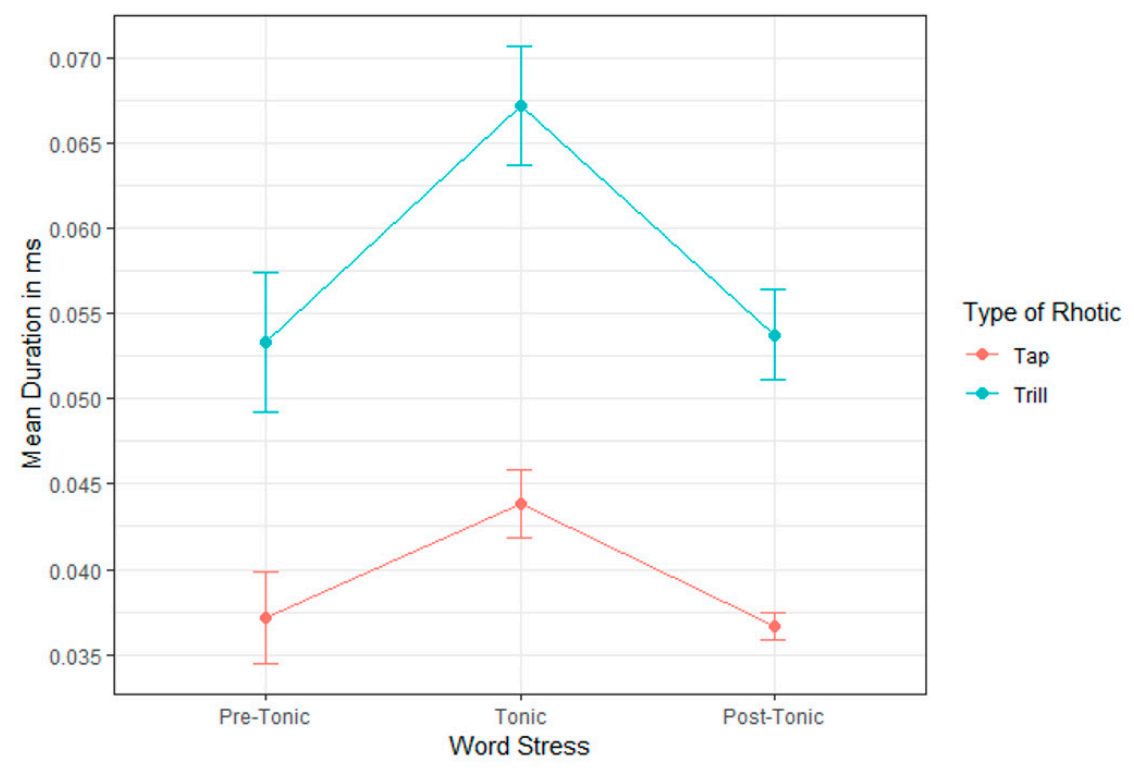


account for any amount of unexplained variation present in the datasets. Likewise, it will control for the grouping factor by taking each individual as a random intercept. Finally, we will avoid problems with multiple comparisons because fewer parameters will be estimated. Therefore, duration values will be considered as our continuous response while type of rhotic (either tap or trill) and word stress (tonic, pretonic and posttonic) will be considered as our independent variables. Table 5 shows the results of the test for all age groups in Raizal Spanish.

As seen in Table 5, results for the test show that pretonic contexts in trills are the most vulnerable to erosion of the tap/trill contrast as compared with the intercept (i.e., taps). Examples extracted directly from the corpus include Barranquilla and verano (i.e., trill pretonic and tap tonic), and corrupción and Caracol (i.e., trill pretonic and tap pretonic). In sum, these analyses reveal that the linguistic phenomenon of the neutralization 146 of the tap/trill contrast is dependent upon position relative to word stress. A closer inspection of segmental duration in these contexts shows a great deal of variability in stressed contexts across generations of bilingual Raizal people. This is visible in Figure 12, where error bars enhance the variability of the plotted data and thus show the range of variability across type of rhotics.

From Figure 12, it can be observed that first-generation bilinguals' duration values of taps and trills overlap in pre-tonic and tonic contexts. For the second generation, there is overlap for taps and trills only in the pre-tonic position. On the contrary, for the third generation, there is no overlap between taps and trills with any word stress. The post-tonic trills have the greatest variability, but there is still no clear overlap with taps. For Continental Spanish, it can be clearly noted that the difference of mean durations between taps and trills is much greater compared to all generations of Raizal Spanish. Furthermore, Continental Spanish has greater mean durations of trills compared to taps across all stress contexts. Specifically, taps remain under the $35 \mathrm{~ms}$ mark.

Table 5 Results of the Mixed Effect Test for the Duration of Non-Vibrant Taps and Trills in Their Stress Context in All Age Groups of Raizal Spanish

\begin{tabular}{lccc}
\hline \multicolumn{1}{c}{ Predictors } & Estimates & $\begin{array}{c}\text { Duration } \\
\text { Cl }\end{array}$ & $\mathbf{p}$ \\
\hline (Intercept) & & $0.03-0.04$ & $<0.001$ \\
stress [pretonic] & 0.03 & $-0.00-0.01$ & 0.992 \\
stress [tonic] & 0.00 & $0.00-0.01$ & $\mathbf{0 . 0 0 1}$ \\
type_rhotic [trill] & 0.00 & $0.01-0.02$ & $<\mathbf{0 . 0 0 1}$ \\
stress [pretonic] *type_rhotic [trill] & 0.01 & $-0.01-0.01$ & 0.630 \\
stress [tonic] * type_rhotic [trill] & 0.00 & $0.00-0.01$ & $\mathbf{0 . 0 0 6}$ \\
Random Effects & 0.01 & & \\
O2 & & & \\
T00 informant & 0.00 & & \\
ICC & 0.00 & & \\
N informant & 0.24 & & \\
Observations & 30 & & \\
Marginal R2 / Conditional R2 & 619 & & \\
\hline
\end{tabular}


Figure 12 Mean Duration of Approximant Taps and Trills in Generations of Bilingual Raizal people (i.e., First, Second, and Third Generation) and Continental Spanish According to Word Stress
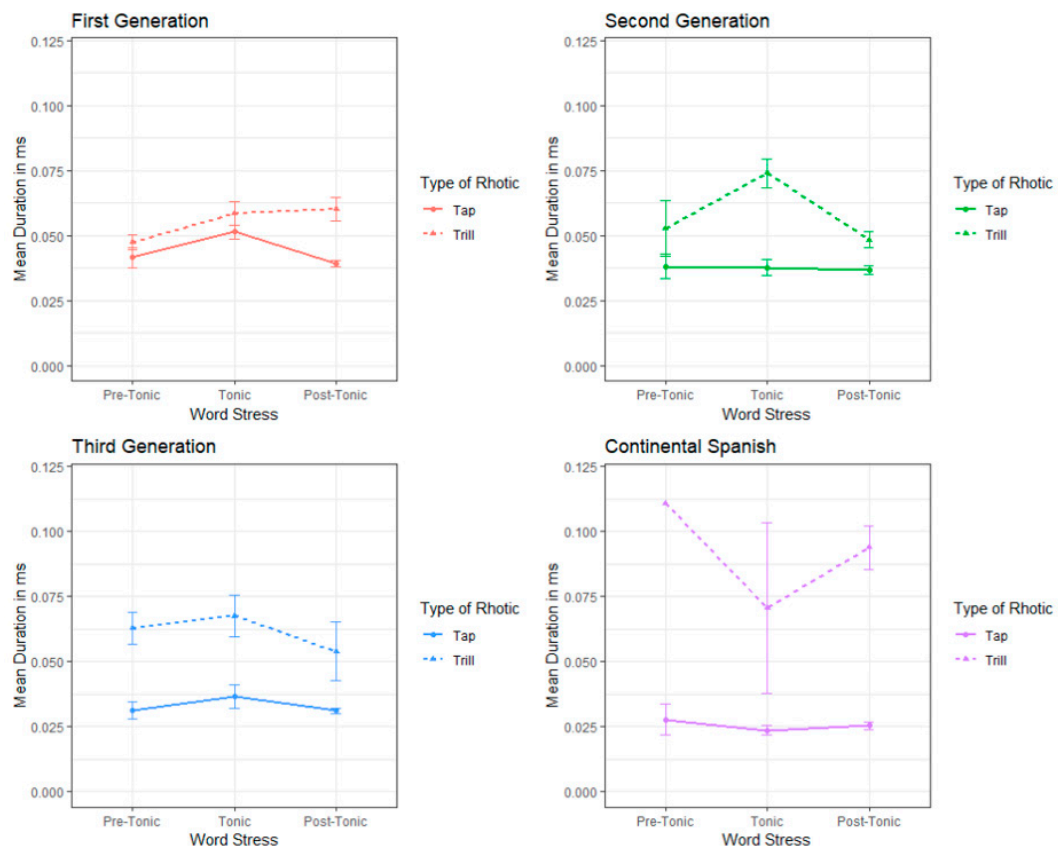

The difference between taps and trills in first generation Raizal individuals is much less pronounced. Specifically, pre-tonic trills and tonic taps in intervocalic positions seem to have overlapping durations, where taps are produced with increasingly higher durations than trills. A detailed inspection of the dataset for the first generation shows that forty-seven tonic taps in first-generation Raizal people were realized with a mean duration of 51.4 milliseconds with values fluctuating 19 milliseconds ( $\mathrm{sd}=0.019)$. In contrast, the sample for pre-tonic trills consisted of 6 tokens with a mean duration of 47.4 milliseconds and a standard deviation value of 0.00684 , which indicates the low variability in segmental duration in this particular context. Despite the low frequency and the fact that only two words with pretonic intervocalic trills appeared in the corpus (Barranquilla and matarratón, a medium-sized tree whose properties are used for pest control), three first-generation informants used these lexical items with duration values ranging from $39 \mathrm{~ms}$ to $57 \mathrm{~ms}$, which suggest that this specific context is vulnerable to short duration trills in older Raizal people.

The statistical test and the graphical visualization of these differences suggest that the variable neutralization of the tap/trill contrast occurs in the older generation of Raizal people in specific contexts, while the speech of the third generation seems to be less permeable to this phenomenon.

\section{Discussion and Conclusions}

As this study has shown, segmental duration has been a useful technique to predict crosslinguistic and cross-generational differences in rhotic production, particularly in contact scenarios, such as the Archipelago of San Andres. The occurrence of both neutralization and maintenance of the Spanish tap/trill contrast in non-vibrant rhotics, which has been known to exist in bilingual and monolingual Spanish settings (Balam, 2013; Henriksen, 2015; Bradley \& Willis, 2012; and others), has also been attested in this bilingual Creole-Spanish community. The first preliminary findings of this study showed that the monolingual Creole and Spanish varieties present contrastive rhotic durations in all word contexts and word stress variables. Such 
differences are language specific and correspond to phonemic realizations proper of each language.

A further comparison in which Raizal Spanish and Continental Spanish were examined in terms of the overall duration of taps and trills ensued. Continental Spanish maintains the phonemic contrast by employing durational cues in tap and trill realizations. However, the bilingual Raizal Spanish variety exhibited the erosion of the durational differences between taps and trills. At this point, it seemed that the outcomes of contact between a non-lexifier language, such as Spanish, and the English-based Islander Creole appeared to involve changes at the phonological level in the bilingual Spanish variety (Aceto, 1999; Snow, 2000). Whether any of the monolingual varieties had a structural influence in the recipient Raizal Spanish was tested across age-stratified samples classified according to three generations of Raizal Spanish informants. As a result, I further examined a possible case of convergence (Matras, 2010; Silva-Corvalan, 1994) in which bilingual approximant taps and trills in intervocalic position are mapping the monolingual Spanish norm in the youngest generation of Raizal individuals.

For this reason, a mixed-effects model was conducted with all generations of Raizal Spanish with the aim of testing the relationship between age and linguistic variety in terms of segmental duration of the intervocalic rhotic contrast. Results showed the lack of a significant effect on non-vibrant trills in pretonic contexts. These results confirmed that rhotic durations in intervocalic contexts differ according to generations of Raizal Spanish speakers. I interpret this finding as a sign of a change in progress in the Archipelago of San Andres. Here, the crucial evidence comes in the second generation, where the neutralization of the contrast gradually starts and is maintained throughout until the oldest generation (see Figure 12). The change comes from below as the neutralization of the tap/trill contrast is inexistent in the youngest generation and is consistent with the monolingual pattern. The abrupt change is categorical and is not apparent in time, as the change is generational rather than individual with a sharp wave-like pattern from second to first generation.

Instead of being an age grading phenomenon, the variation presented across generations of Raizal Spanish speakers suggests that individual changes have an effect in the abrupt generational change from third to first and second generations. The direction of change shows that the neutralization feature is eliminated abruptly in younger speakers who pattern the monolingual maintenance. This is further evidenced by the fact that the neutralization in the older second and first generations appears in pretonic and tonic contexts. The first generation has both pretonic and tonic contexts susceptible to erosion of the tap/trill contrast, while the pretonic tap/trill context are predominant in the second generation. All this suggests that the neutralization is both constrained by linguistic factors and the age stratified sample.

In sum, results showed that neutralization takes place across specific word stress combinations in both taps and trills and that the effect of this phenomenon is prevalent in older first and second generations, respectively. The neutralization pattern is also present in second generation informants but non-existent in younger, third-generation Raizal people. This is the first result that indicated a change in progress in the Archipelago of San Andres, as some bilingual taps and trills conditioned by word stress remain indistinguishable in terms of segmental duration in senior Raizal individuals and second-generation informants (Díaz-Campos, 2008; Thomason, 2020). On the contrary, the tap/trill contrast is maintained in younger generations.

From a functional perspective, the purpose of the maintenance is to minimize confusion in meaning with the minimal pairs thathold the tap/trill contrast in Spanish. As seen in previous studies (MeleroGarcía \& Cisneros, 2020; Willis \& Bradley, 2008), durational differences are sufficient to maintain 
the contrast in monolingual varieties and are used here as well to keep these differences between taps and trills in both Continental Spanish and third generation Raizal Spanish speakers. The restructuring of the phonological categories between taps and trills (Wienreich, 1953; Klee \& Lynch, 2009) gives further evidence of a change in progress in the approximant rhotics of the bilingual Spanish variety spoken by generations of Raizal populations. This seems to be supported by the phonological transfer of the languages in contact, Spanish and Creole (Silva-Corvalan, 1994). Although the evidence of the neutralization of the tap/trill contrast suggests convergence of phonological categories to Continental Spanish, this partially explains the reason behind the neutralization phenomenon in the intervocalic taps and trills of the archipelago. Rather, the sociolinguistic background of the islands can help to explain this contact outcome.

The maintenance of the tap/trill contrast is likely to be a sign of language dominance and early bilingualism in the youngest Raizal population (Amengual, 2018). Younger Raizal individuals are educated in Spanish and increasingly seeking education in universities of mainland Colombia, where Spanish is the main language of instruction and social interaction. Moreover, similar to other phonological variables in bilingual varieties of Spanish in contact with English (Lynch, 2009), normatively contrasted non-vibrant taps and trills seem to be retained due to ascription to a social group.

Ongoing language change has been suggested to be accelerated in cases where prestigious normative variants are less restricted in their contexts of use (Silva-Corvalán, 1994), as in Colombian Spanish, which is deemed as the language of business and educational success. External social concerns play a crucial role in the nature of rhotic variation in the Archipelago of San Andres, as it seems that the third generation Raizal people mark their speech with phonological variables more in line with the prestigious national language of Spanish. The sociolinguistic situation in the archipelago is twofold due to the social and economic implications brought about by the overpopulation of the island of San Andres (Bartens, 2013; Moya, 2014). There, the situation is aggravated by the unstable relationship between Islander Creole and Continental Spanish, where Islander Creole is losing contexts of use and increased by the new generations of more proficient Creole-Spanish bilinguals, who are educated in Spanish as the only language of instruction. In contrast, Raizal population composes the vast majority of the population of Old Providence, and Islander Creole maintains its allocated niche within the Raizal household.

Since this study used naturalistic data for the analysis of the tap/trill contrast, the design of the project could have included other social variables, such as socioeconomic class and speaker sex within the stratified age samples so as to be more precise in terms of social mechanisms in play in the archipelago. This is a limitation that should be addressed in future work. In addition, both the intergenerational and crosslinguistic comparisons presented in this paper offer methodological insights for further research in contact scenarios where a Creole and a non-lexifier language coexist. First, the languages in contact were compared according to the overall durational differences. Moreover, the monolingual Spanish variety was contrasted with the aim, revealing confounding patterns of variation with generations of Raizal Spanish speakers. These comparisons allowed to establish real time evidence of generational convergence towards Spanish in younger Raizal Spanish speakers.

This study has provided evidence of the neutralization of the tap/trill contrast suggesting convergence of phonological categories to one of the contact languages. Moreover, the results of this study have shed light on the mechanisms of linguistic change in the rhotics of the archipelago, as one of the outcomes of language contact in the bilingual speech of an island community coexisting with Spanish, the national language of Colombia. As such, the Archipelago of San Andres has set the stage 
for documenting the outcomes of contact between a Creole and a non-lexifier language (Aceto, 1999; Snow, 2000), providing an account of language variation and change in rhotic production across generations of bilingual Raizal individuals.

\section{References}

Aceto, M. (1999). Looking beyond decreolization as an explanatory model of language change in creolespeaking communities. Journal of Pidgin and Creole Languages, 14(1), 93-119. https://doi. org/10.1075/jpcl.14.1.04ace

Aikhenvald, A. Y. (2006). Grammars in contact: A cross-linguistic perspective. In A. Aikhenvald, \& R. Dixon, (Eds.), Grammars in contact: A cross-linguistic typology (pp. 1-54), Oxford University Press.

Amengual, M. (2018). Asymmetrical interlingual influence in the production of Spanish and English laterals as a result of competing activation in bilingual language processing. Journal of Phonetics, 69, 12-28. https:// doi.org/10.1016/j.wocn.2018.04.002

Balam, O. (2013). Neutralization of the intervocalic rhotic contrast in Northern Belizean Spanish. Borealis-An International Journal of Hispanic Linguistics, 2(2), 285-315. https://doi.org/10.7557/1.2.2.2601

Bartens, A. (2013). San Andres Creole English. The Survey of Pidgin and Creole Languages, 1, 101-114.

Bartens, A. (2002). Another short note on Creoles in contact with non-lexifier prestige languages. Journal of Pidgin and Creole Languages, 17(2), 273-278. https://doi.org/10.1075/jpcl.17.2.08bar

Boersma, P., \& Weenink, D. (2020). PRAAT: Doing phonetics by computer [Computer program]. Version 6.1.09. http://www.praat.org/

Bradley, T. G., \& Willis, E. W. (2012). Rhotic variation and contrast in Veracruz Mexican Spanish. Estudios de Fonética Experimental, 21, 43-74.

Bradley, T. G. (2006). Spanish rhotics and Dominican hypercorrect/s. Probus, 18(1), 1-33. https://doi. org/10.1515/PROBUS.2006.001

Bradley, T. G. (1999). Assibilation in Ecuadorian Spanish. In Formal perspectives on romance linguistics (pp. 57-71). Selected papers from the $28^{\text {th }}$ Linguistics Symposium on Romance Languages. John Benjamins Publishing Company. https://doi. org/10.1075/cilt.185.06bra
Cedergren, H. (1973). The interplay of social and linguistic factors in Panama. (Doctoral dissertation), Cornell University, NY, USA.

Chang, C. B., Yao, Y., Haynes, E. F., \& Rhodes, R. (2011). Production of phonetic and phonological contrast by heritage speakers of Mandarin. The Journal of the Acoustical Society of America, 129(6), 3964-3980. https://doi.org/10.1121/1.3569736

Colantoni, L. (Ed.) (2006). Increasing periodicity to reduce similarity: An acoustic account of deassibilation in rhotics. Cascadilla Proceedings Project.

Cummings Ruiz, L. D., \& Montrul, S. (2020). Assessing rhotic production by bilingual Spanish speakers. Languages, 5(4), 51. https://doi. org/10.3390/languages 5040051

DANE - Colombia National Administrative Department of Stastistics (2018). 2018 Census of Colombia. [Online] Accessed on May 2021. http://systema59. dane.gov.co/bincol/RpWebEngine.exe/Portal?BAS $\mathrm{E}=\mathrm{CNPVBASE} 4 \mathrm{~V} 2 \&$ lang $=\mathrm{esp}$

DANE - Colombia National Administrative Department of Statistics (2005). 2005 Census of Colombia. [Online] Accessed on October 2020. http://systema59.dane.gov.co/cgibin/RpWebEngine.exe/Port alAction?\&MODE $=$ MAIN\&BASE $=$ CG2005BA SICO\&MAIN=WebServerMain.inl

Díaz-Campos, M. (Ed.) (2008). Variable production of the trill in spontaneous speech: Sociolinguistic implications. Cascadilla Proceedings Project.

Díez-Canseco, S. (1997). Language variation: The influence of speakers' attitudes and gender on sociolinguistic variables in the Spanish of Cusco, Peru (Doctoral dissertation) University of Pittsburgh, USA.

Dittmann, M. (1992). El criollo sanandresano: lengua y cultura. Universidad del Valle.

Eckert, P. (2017). Age as a sociolinguistic variable. In F. Coulmas (Ed.), The handbook of sociolinguistics (pp.151-167). https://doi. org/10.1002/9781405166256.ch9

Edwards, J. (1974). African influences on the English of San Andres Island, Colombia. In D. DeCamp \& I. Hancock (Eds.), Pidgins and Creoles: Current trends and prospects (pp. 1-26). Georgetown University Press.

Hammond, R. (1999). On the non-occurrence of the phone $[\mathrm{r}]$ in the Spanish sound system. In J. Gutiérrez-Rexach \& F. Martínez-Gil (Eds.), Advances in Hispanic linguistics (pp. 135-151). Papers from the $2^{\text {nd }}$ Hispanic Linguistics Symposium, Ohio State University, USA. 
Heine, B., \& Kuteva, T. (2003). On contact-induced grammaticalization. Studies in Language, 27(3), 529-572. https://doi.org/10.1075/sl.27.3.04hei

Henriksen, N. (2015). Acoustic analysis of the rhotic contrast in Chicagoland Spanish. Linguistic Approaches to Bilingualism, 5(3), 285-321. https://doi. org/10.1075/lab.5.3.01hen

Henriksen, N. (2014). Sociophonetic analysis of phonemic trill variation in two sub-varieties of Peninsular Spanish. Journal of Linguistic Geography, 2(1), 4-24. https://doi.org/10.1017/jlg.2014.1

Henriksen, N. C., \& Willis, E. W. (2010). Acoustic characterization of phonemic trill production in Jerezano Andalusian Spanish. In Selected proceedings of the $4^{\text {th }}$ Conference on Laboratory Approaches to Spanish Phonology (pp. 115-127). Cascadilla Proceedings Project.

Holm, J. (2000). An introduction to Pidgins and Creoles. Cambridge University Press. https://doi. org/10.1017/CBO9781139164153

Holm, J. A. (1978). The Creole English of Nicaragua's Coast: Its sociolinguistic history and a comparative study of its lexicon and syntax (Doctoral dissertation), University College, London.

Hualde, J. I. (2005). The sounds of Spanish with audio CD. Cambridge University Press.

Kent, R. D., \& Read, C. (2002). Acoustic analysis of speech $\left(2^{\mathrm{n}} \mathrm{d}\right.$ Ed.). Singular/Thomson Learning.

Klee, C., \& Lynch, A. (2009). Capítulo 1: Introducción. El español en contacto con otras lenguas (pp. 1-24). Georgetown University Press.

Labov, W. (2001). Principles of linguistic change (vol. 2 Social factors. Language in Society series, v. 29). Blacwell.

Ladefoged, P., \& Maddieson, I. (1996). The sounds of the world's languages (vol. 1012). Blackwell Oxford.

Lastra, Y., \& Buitragueño, P. M. (2006). Un posible cambio en curso: el caso de las vibrantes en la ciudad de México. Estudios sociolingüisticos del español de España y América (pp. 35-68). https://doi. org/10.2307/j.ctv47w546.11

Lennes, M. (2002). PRAAT script for automatic extraction of segmental duration [Online] http://phonetics. linguistics.ucla.edu/facilities/acoustic/praat.html

Lipski, J. (2011). Socio-phonological variation in Latin American Spanish. The Handbook of Hispanic Sociolinguistics (pp. 72-97). https://doi. org/10.1002/9781444393446.ch4

Lipski, J. (1994). Latin American Spanish. Addison-Wesley.
Lynch, A. (2009). A sociolinguistic analysis of final/s/ in Miami Cuban Spanish. Language Sciences, 31(6), 766-790. https://doi.org/10.1016/j. langsci.2008.08.002

Matras, Y. (2010). Contact, convergence, and typology. In R. Hickey (Ed.), The handbook of language contact (p. 66). Wiley-Blackwell. https://doi. org/10.1002/9781444318159.ch3

Mayer, M. (1969). Frog, where are you? Dial Press New York.

Melero-García, F., \& Cisneros, A. (2020). No es tan simple como parece. Current Theoretical and Applied Perspectives on Hispanic and Lusophone Linguistics, 27, 295. https://doi.org/10.1075/ihll.27.14mel

Morgan, T. A., \& Sessarego, S. (2016). A phonetic analysis of intervocalic /r/ in Highland Bolivian Spanish. Spanish in Context, 13(2), 195-211. https://doi. org/10.1075/sic.13.2.02mor

Morren, R. (2001). Creole-based trilingual education in the Caribbean archipelago of San Andres, Providence and Santa Catalina. Journal of Multilingual and Multicultural Development, 22(3), 227-241. https://doi.org/10.1080/01434630108666434

Moya, D. S. (2014). La situación sociolingüística de la lengua creole de San Andrés Isla: el caso de San Luis. Colombian Applied Linguistics Journal, 16(1). https:// doi.org/10.14483/udistrital.jour.calj.2014.1.a05

Patiño Rosselli, C. (1992). La criollística y las lenguas criollas de Colombia. Thesaurus: Boletín del Instituto Caro y Cuervo, 47(2), 233-264.

Recasens, D., \& Pallarès, M. D. (1999). A study of/J/and/r/ in the light of the "DAC" coarticulation model. Journal of Phonetics, 27(2), 143-169. https://doi. org/10.1006/jpho.1999.0092

Restrepo-Ramos, F. (2019). A sociophonetic analysis of Islander Creole rhotics. Proceedings of the Florida Linguistics Yearly Meeting, 6(1), pp. 76-90.

Ross, J. (2007). Routes for roots: entering the $21^{\text {st }}$ century in San Andres Island, Colombia. Caribbean Studies, 35(1), 3-36.

Sankoff, G. (2002). Linguistic outcomes of language contact. In J. K. Chambers, P. Trudgill, \& N. Schilling-Estes (Eds.), The handbook of language variation and change. Wiley Online Library.

Silva-Corvalán, C. (1994). Language contact and change: Spanish in Los Angeles. Oxford University Press.

Snow, P. (2000). Language variation in Caribbean Creole/ non-lexifier. Contact situations: Continua or diglossia. Texas Linguistic Forum, 44(1), 148-162 (Eighth 
Annual Symposium about Language and Society, Austin. Texas, USA). http://salsa.ling.utexas.edu/ proceedings/2000/snow.pdf

Solé, M.-J. (2002). Aerodynamic characteristics of trills and phonological patterning. Journal of Phonetics, 30(4), 655-688. https://doi.org/10.1006/jpho.2002.0179

Team, R. C. (2013). R: A language and environment for statistical computing. http://www.R-project.org/

Thomas,E.(2011).Sociophonetics: Anintroduction.PalgraveMacmillan. https://doi.org/10.1007/978-1-137-28561-4

Thomason, S. (2020). Contact explanations in linguistics. The handbook of language contact (pp. 31-49). https:// doi.org/10.1002/9781119485094.ch1

Thomason, S. G. (2001). Language contact: An introduction. Georgetown University Press. https://doi. org/10.1016/B0-08-043076-7/03032-1
Weinreich, U. (1953). Languages in contact. Mouton.

Willis, E. W., \& Bradley, T. G. (2008). Contrast maintenance of taps and trills in Dominican Spanish: Data and analysis. Paper presented at the Selected proceedings of the $3^{\text {rd }}$ Conference on Laboratory Approaches to Spanish Phonology. Victoria College at the University of Toronto, Canada.

Zahler, S., \& Daidone, D. (2014). A variationist account of trill/r/usage in the Spanish of Málaga. IULC Working Papers, 14(2).

Zhou, X., Espy-Wilson, C. Y., Boyce, S., Tiede, M., Holland, C., \& Choe, A. (2008). A magnetic resonance imaging-based articulatory and acoustic study of "retroflex" and "bunched" American English/r. The Journal of the Acoustical Society of America, 123(6), 4466-4481. https:// doi.org/10.1121/1.2902168

How to cite this article: Restrepo-Ramos, F. D. (2022). Neutralization of the tap/trill contrast in the bilingual Creole-Spanish community of the archipelago of San Andres, Colombia. Íkala, Revista de Lenguaje y Cultura, 27(1), 126-152. https://doi.org/10.17533/udea.ikala.v27n1a07 